Article

\title{
Evaluation of Energy and Daylight Performance of Old Office Buildings in South Korea with Curtain Walls Remodeled Using Polymer Dispersed Liquid Crystal (PDLC) Films
}

\author{
Myunghwan $\mathrm{Oh}^{1}$, Chulsung Lee ${ }^{2, *}{ }^{\mathbb{C}}$, Jaesung Park ${ }^{3, *}$, Kwangseok Lee ${ }^{4}$ and Sungho Tae ${ }^{5, *}$ \\ 1 Energy Efficiency Building Materials Center, Energy Division, Korea Conformity Laboratories (KCL), 595-10, \\ Pyengsin 1-ro, Daesan-eup, Seosan-si 31900, Chungnam, Korea; mhoh@kcl.re.kr \\ 2 Future agricultural Research Division, Korea Rural Research Institute, 870, Haean-ro, Sangnok-gu, Ansan-si, \\ 15634, Gyeonggi-do, Korea \\ 3 Energy Efficiency Building Materials Center, Energy Division, Korea Conformity Laboratories (KCL), 73, \\ Yangcheong 3-gil, Ochang-eup, Cheongju-si 28115, Chungbuk, Korea \\ 4 Research and Development Center, Bestroom corporation, 106-46, Gwahakdangi-ro, Gangneung-si, 25440, \\ Gangwon-do, Korea; lks@bestroom.co.kr \\ 5 School of Architecture \& Architectural Engineering, Hanyang University, 55 Hanyangdaehak-ro, \\ Sangrok-gu, Ansan-si 15588, Gyeonggi-do, Korea \\ * Correspondence: csleekor@ekr.or.kr (C.L.); la107@kcl.re.kr (J.P.); jnb55@hanyang.ac.kr (S.T.); \\ Tel.: +82-10-9510-5565 (C.L.); +82-43-718-9010 (J.P.); +82-31-400-5187 (S.T.)
}

Received: 21 August 2019; Accepted: 25 September 2019; Published: 26 September 2019

\begin{abstract}
Globally, energy standards for new buildings are being reinforced to improve energy efficiency, and remodeling policies are being promoted for old buildings. The South Korean Government is promoting green remodeling projects, and focusing on research and product development to improve the performance of old windows and curtain walls. In line with this, the present study proposes two remodeling methods using polymer dispersed liquid crystal (PDLC) films, which can adjust solar radiation for old office buildings. In addition, energy efficiency improvement and daylight performance according to remodeling were analyzed. Attaching PDLC films to the glass of old curtain walls was analyzed; this can reduce heating and cooling energy, reduce the annual discomfort glare occurrence rate, and increase the annual indoor appropriate illuminance ratio. Furthermore, producing a window by laminating a PDLC film between two sheets of glass and putting it over the existing curtain wall was also analyzed; this can reduce annual building energy consumption and the annual discomfort glare occurrence rate, and improve the annual indoor appropriate illuminance ratio. Therefore, PDLC film is expected to be applicable as a next-generation green remodeling material because using it in remodeling can improve energy efficiency of old office buildings and indoor daylight performance.
\end{abstract}

Keywords: polymer dispersed liquid crystal; green remodeling; building energy efficiency; EnergyPlus

\section{Introduction}

\subsection{Research Background and Objective}

Efforts are being made worldwide to reduce energy consumption in the building sector in order to address global warming, extreme weather events, and resource depletion challenges. The South Korean Government has also presented a roadmap to reduce energy consumption to zero in all new 
buildings by 2025 and is striving to improve energy efficiency for new buildings while gradually strengthening regulations related to building energy. South Korea has over 6.8 million buildings aged 15 years or more. As an effort to improve energy efficiency [1,2] for existing buildings as well as new ones, the South Korean government is promoting the green remodeling project. Seoul City, which has the largest number of buildings in South Korea, is separately promoting the building retrofit project [3].

Among the energy efficiency improvement projects for old buildings in South Korea, the most active project is building envelope performance improvement. Most activities are focused on improving insulation performance, for which frames using low-emissivity glass, argon gas, triple glass, and thermal bridging insulation materials are mainly applied. However, to implement zero-energy buildings [4,5], solar radiation control is crucial as well as insulation performance. Particularly in South Korea, where the winter and summer weather are clearly distinguished, the solar radiation inflow and blocking control of building envelopes can have a significant effect in terms of energy efficiency [6]. It is important to improve energy-related heat transmission rates and solar radiation control in order to enhance the performance of a building envelope; however, when retrofitting old buildings, structural stability must also be considered [7]. Furthermore, the development and application of building materials using renewable energy such as building integrated photovoltaics (BIPV) also play a significant role in the implementation of zero-energy buildings [8].

A general method to improve the solar radiation control performance of building envelopes has been applying separate shading devices such as blinds and roll shades. However, these sunshade devices require separate construction work, and rational control for energy reduction is not being conducted because they are manually controlled by users according to the external environment [9].

Consequently, technology for solar radiation control, such as smart glasses that can control transmittance by glass itself, is under active development and is anticipated as a next-generation solar radiation control device. Various types of smart glass products are being developed, such as polymer dispersed liquid crystal (PDLC), electrochromic (EC), thermochromic (TC), and photochromic (PC) products [10]. The advantage of these smart glass products is that they can control transmittance through the glass itself without a shading device and can easily control transmittance using electric signals [11-14].

Each type of smart glass has its own advantages and disadvantages. PDLC is most economical among smart glasses and has a quick response speed of less than one second [15]. The transmittance control property of PDLC can be varied by changing the material in the production stage. A PDLC that can control transmittance in the desired range between visible rays and total solar spectrum can be implemented [16]. Moreover, since PDLC can be easily produced as films, laminated glasses can be made through lamination between glass substrates, thus providing the advantage of attaching it to existing glasses as a film. Furthermore, PDLC can be used for privacy product as well as for energy efficiency improvement as exterior materials because it can separately implement transparent and opaque conditions [17]. By contrast, PDLC has the disadvantages of requiring continuous electricity supply to maintain transparent conditions and it has a narrow range of transmittance according to ON/OFF [18].

EC glass has the advantage of a broad range of transmittance for the entire solar spectrum according to coloring and discoloration, and possibility to operate at voltages below $5 \mathrm{~V} \mathrm{[19].} \mathrm{In} \mathrm{addition,} \mathrm{it} \mathrm{can}$ maintain its state without applying electricity when it reaches the desired transmittance if the electricity is only applied at the time of transmittance change [20]. By contrast, EC glass has the disadvantage of slow response speed at the time of transmittance change; it generally takes more than $10 \mathrm{~min}$ [21-28]. TC glass is characterized by changing transmittance according to ambient temperature, and PC glass is characterized by changing transmittance according to surrounding brightness [29-31]. The advantage of TC and PC glass is that they can control transmittance with no separate power device and the disadvantage is that the transmittance is controlled even when the user does not want it to be [32].

Among these smart glass products, PDLC film is most widely commercialized in South Korea owing to its economic efficiency, fast response, and durability. The market size of PDLC films in the 
interior market is growing rapidly and various research and product developments are being carried out for application as exterior materials such as yellowing prevention through UV screen coating and selective control of lighting through patterning using laser etching. It is also expected to be applied as a next-generation building solar radiation control device.

Therefore, in this study, curtain wall remodeling of old office buildings is performed by using the experimental analysis results for optical and thermal properties of PDLC films that can control four solar spectrum transmissivities developed by our research team. Furthermore, the heating and cooling energy efficiency improvement effect, discomfort glare reduction effect, and indoor appropriate illuminance performance are evaluated using dynamic building energy simulation. Two remodeling methods using PDLC films are also proposed and the possibility of using PDLC films as building materials for green remodeling of old buildings in South Korea is evaluated through energy and daylight performance evaluation.

\subsection{Research Method and Scope}

In this study, two curtain wall remodeling methods using PDLC films for old office buildings are proposed. The first method is to attach films to the glass of existing old curtain walls, and the second method is to produce a window frame by laminating a PDLC film between glass substrates and putting it over the existing old curtain walls. Then, the building energy and daylight performance of these two remodeling methods are evaluated through simulations based on the results of optical properties analysis experiments on PDLC films.

For the optical properties analysis experiment performed on PDLC films, four types of specimens were fabricated according to the solar spectrum transmittance property, and the optical properties data were collected as a txt file using a spectrometer. In addition, from the optical properties data of the PDLC films, the average transmittance, reflectance, absorptivity, and emissivity data for the spectrum range (300-2500 nm) were derived using Optic 6 of the Lawrence Berkeley National Laboratory (LBNL) [33].

To implement the first remodeling method, the glazing data of existing old curtain walls were extracted by using Optic 6 from the International Glazing Database (IGDB) of the LBNL. Subsequently, the optical and thermal properties data of the glass with a PDLC film were derived by using the analyzed optical properties data for PDLC films. To implement the second remodeling method that puts a PDLC window over the existing curtain wall, the optical and thermal properties data of the laminated glasses were derived from the IGDB data of the LBNL and the optical properties data for PDLC films. In this way, the optical and thermal properties data of the two types of remodeled curtain walls were derived after the curtain walls including frames were configured from the optical and thermal properties data of the glass with a PDLC film and the laminated glass by using Window 7.4 and Therm 7.4 of the LBNL [34,35].

To evaluate the building energy and daylight performance, an EnergyPlus 8.5 simulation was used in this study. The performance improvement effect was analyzed through the ratios of heating and cooling energy, discomfort glare, and indoor appropriate illuminance relative to the existing old curtain walls after entering the data derived from Window 7.4 and Therm 7.4 of the LBNL. Figure 1 describes the research method in general. 

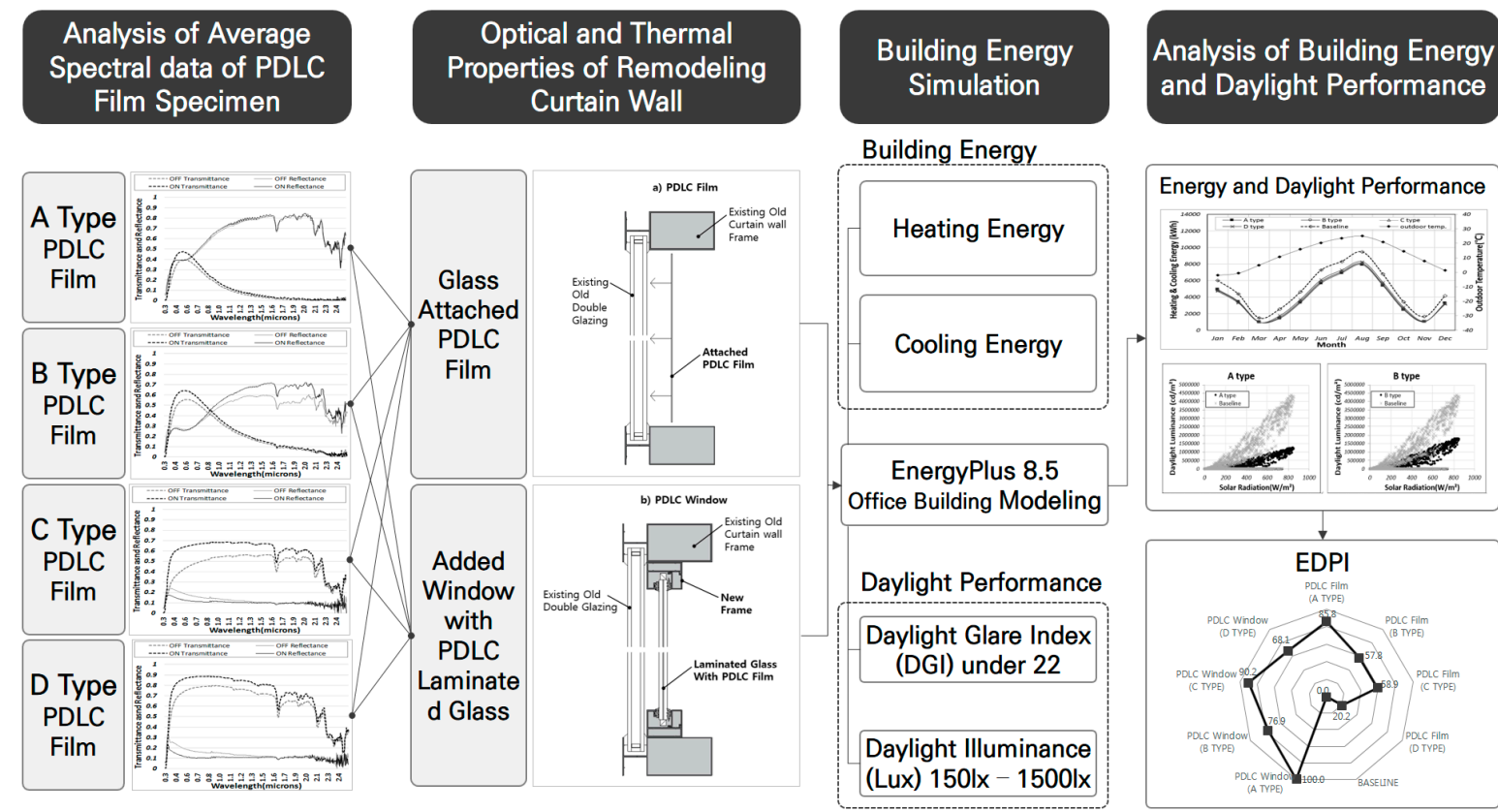
and Daylight Performance
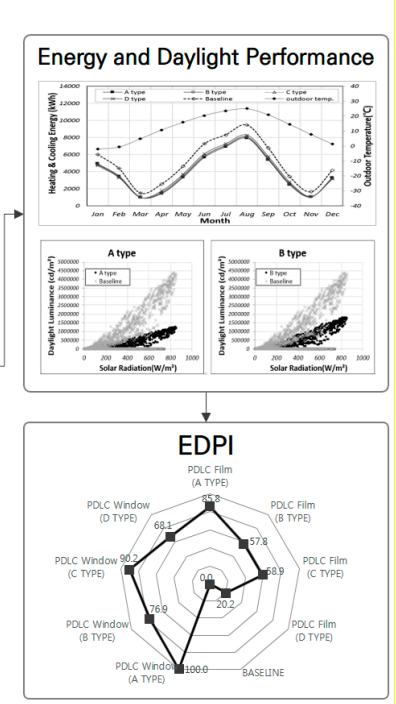

Figure 1. Research guideline and flowchart.

\section{Optical Properties of PDLC Film}

Our research team developed four types of PDLC films and conducted experiments using a spectrometer to examine the optical properties of PDLC films as building materials. To analyze their optical properties, four types of PDLC film specimens, with a size of $50 \mathrm{~mm} \times 50 \mathrm{~mm}$ were fabricated, as shown in Figure 2. Transmittance, front reflectance, back reflectance, front emissivity, and back emissivity in the solar spectrum range of $0.3-2.5 \mu \mathrm{m}$ were measured using a spectrometer. The transmittance and reflectance were measured in two modes, ON and OFF, for each PDLC film. The PDLC film became transparent when electricity was switched ON and translucent when electricity was switched OFF. Here, the voltage applied to the PDLC was $110 \mathrm{~V}$ and the applied current was $0.5 \mathrm{~A}$ in the switched ON condition.

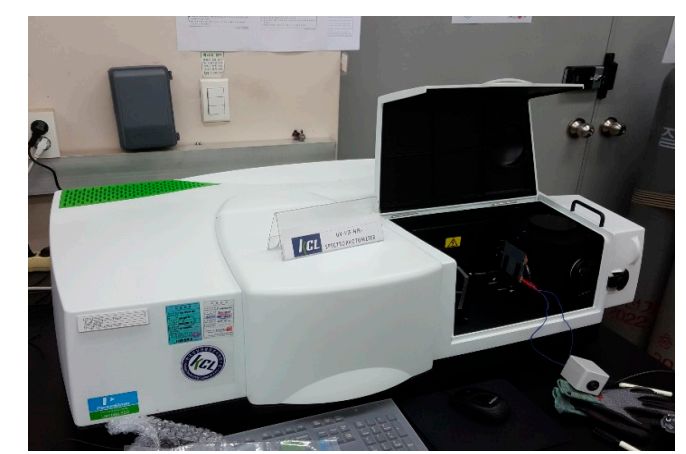

(a)

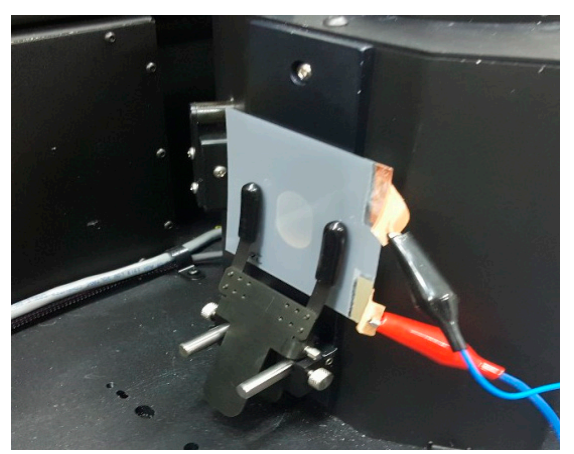

(b)

Figure 2. Spectrometer (a) and polymer dispersed liquid crystal (PDLC) film specimen (b).

Figure 3 shows a raw data graph of the PDLC film analyzed by the spectrometer. To examine the optical properties of the four types of PDLC films, the graphs of A and B type PDLC films focus on the change of transmittance in the visible light range depending on ON/OFF modes. The graphs of $C$ and $\mathrm{D}$ type PDLC films show a wide range of transmittance in the visible light and near infrared (NIR) regions depending on ON/OFF modes. 


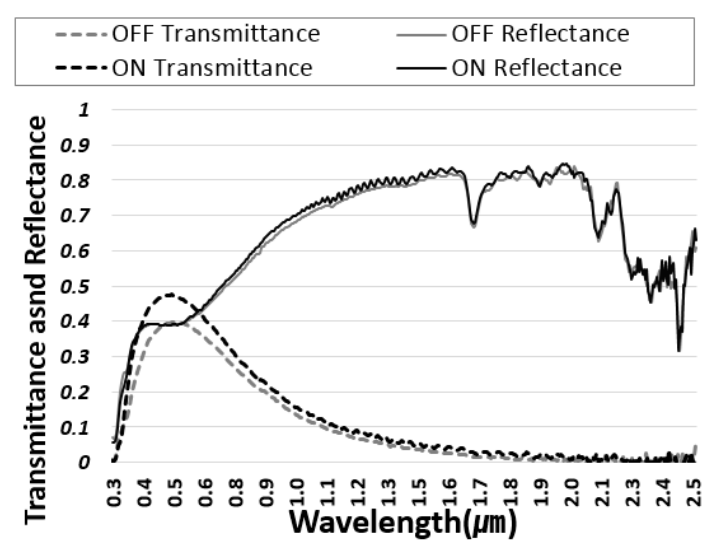

(a)

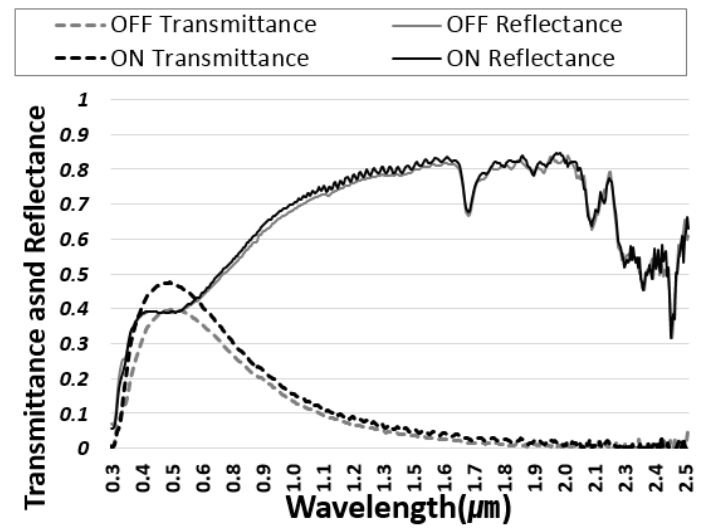

(c)

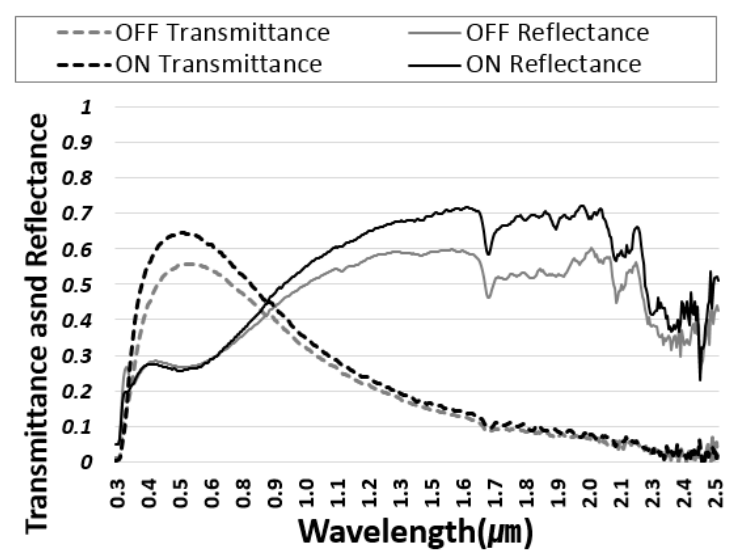

(b)

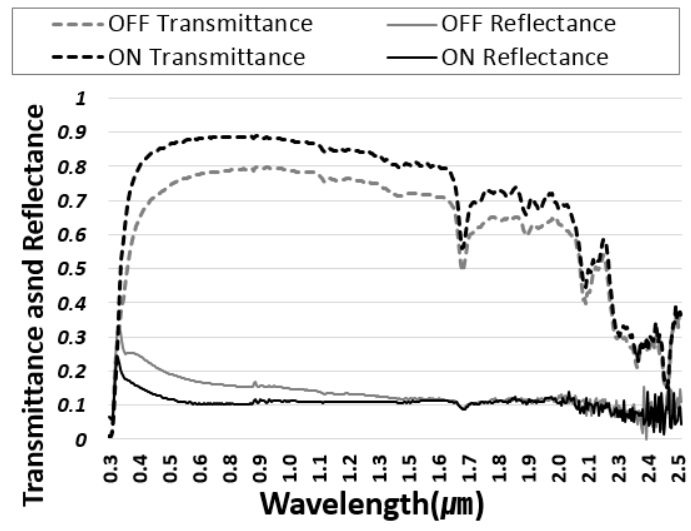

(d)

Figure 3. Optical properties data by PDLC film type.

In this study, the attached PDLC film for remodeling and remodeling PDLC window were configured using LBNL's Window 7.4 and Therm 7.4 based on the raw data derived through a spectrometer, and then the solar heat gain coefficient (SHGC) and thermal properties were derived. Therefore, the raw data first need to be converted so that they could be used in Window 7.4 and Therm 7.4.

From the analysis of the PDLC specimens using a spectrometer, transmittance and reflectance raw data in $0.005 \mu \mathrm{m}$ units in the range of $0.3-2.5 \mu \mathrm{m}$ were derived and the data were saved as a txt file. To input the raw data in the txt file into the Window 7.4 and Therm 7.4 programs, they were converted to average spectral data. In this study, the raw data were converted to solar $(0.3-2.5 \mu \mathrm{m})$ transmittance and reflectance and visible $(0.38-0.78 \mu \mathrm{m})$ transmittance and reflectance by using the Optic 6 program developed by LBNL. The solar transmittance and reflectance represented the transmittance and reflectance in the ultraviolet, visible, and infrared spectrum ranges. The visible transmittance and reflectance represented the transmittance and reflectance in the visible spectrum range.

Table 1 lists the data derived through the Optic 6 program. Solar transmittance had a direct effect on the cooling and heating loads of buildings. An analysis of the average spectral data revealed that based on the OFF state where the sunlight was blocked, type A had the lowest solar transmittance, followed by types B, C, and D with values of $0.230,0.390,0.472,0.733$, respectively. Hence, solar transmittance gradually increased from $\mathrm{A}$ to $\mathrm{D}$ types. The transmittance variation range of solar transmittance for types A, B, C, and D was $0.043,0.054,0.166$, and 0.100 , respectively. Thus, type $\mathrm{C}$ had the largest transmittance variation range, followed by types $\mathrm{D}, \mathrm{B}$, and $\mathrm{A}$. 
Table 1. Optical properties data by PDLC film type derived using Lawrence Berkeley National Laboratory (LBNL) Optic 6 program.

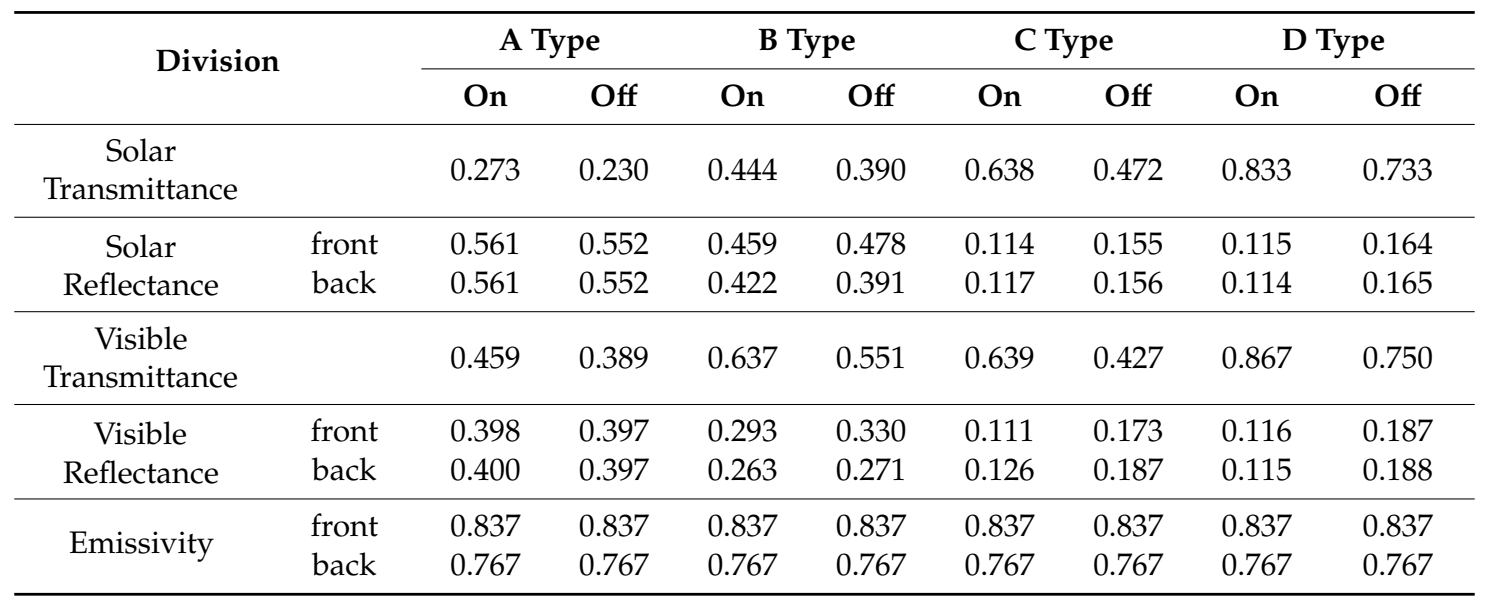

\section{Old Curtain Wall Remodeling Method Using PDLC Film}

\subsection{Overview of the Old Curtain Wall Remodeling Method Using PDLC Film}

PDLC film can be switched to transparent or translucent states by turning electricity ON or OFF. Therefore, privacy can be secured by visually blocking light from the outside, and in terms of building energy, it can be used as a solar radiation control device for reducing heating and cooling energy because the transmission range can be adjusted over the entire solar spectrum.

As stated in the introduction, South Korea is reinforcing policies and regulations for new buildings to reduce their energy consumption and is striving to improve building energy efficiency of old buildings through green remodeling and building retrofit projects.

This study proposes a method of improving building energy efficiency by applying PDLC films to curtain walls that are mainly used in old office buildings in South Korea. Office buildings are expected to obtain energy reduction effects when solar radiation control devices such as PDLC films are applied because they are greatly affected by solar radiation due to their large window areas.

The glazing specifications of existing old curtain walls were assumed to be $26 \mathrm{~mm}$ double glazing (6 mm clear glass $+14 \mathrm{~mm}$ air $+6 \mathrm{~mm}$ clear). As shown in the optical and thermal properties in Table 2, the heat transmission rate is $2.813 \mathrm{~W} / \mathrm{m}^{2} \mathrm{~K}$, the solar heat gain coefficient is 0.697 , and the visible transmittance is 0.771 . For the optical and thermal properties of double glazing, the LBNL's Window 7.4 program was used. For the glass for simulation, the clear glass of KCC Corporation (IGDB No.13503) provided by the IGDB was applied. The environmental conditions were derived at the indoor temperature of $20^{\circ} \mathrm{C}$ and the outdoor temperature of $0{ }^{\circ} \mathrm{C}$ in accordance with Korean Industrial Standard (KS) [36]. It was assumed that no thermal bridging insulation material was applied to the curtain wall frame considering the old building condition. The heat transmission rate of the old curtain wall frame was calculated by using LBNL's Therm 7.4 program. As shown in Table 2, the heat transmission rate data for each part were derived [37].

A curtain wall system that included both glazing and frame was finally set up by using Window 7.4 based on the optical and thermal property data for double glazing and frames. The curtain wall system had a size of $2 \mathrm{~m} \times 2 \mathrm{~m}$ and included a divider at the horizontal center in accordance with KS. The U-values of the frame and edge parts of the existing old curtainwall were obtained by establishing a model using LBNL's Therm 7.4 program; the model was then analyzed according to an indoor temperature of $20^{\circ} \mathrm{C}$ and an outdoor temperature of $0{ }^{\circ} \mathrm{C}$ based on the Korean Industrial Standard (KS). The modeling results of the Therm 7.4 program are shown in Table 8 in Section 3.3, which compares the modeling shapes and U-values before and after remodeling. Table 3 outlines the analysis results of the optical and thermal 
properties of the existing old curtain wall system. As shown in Table 3, the heat transmission rate was $3.816 \mathrm{~W} / \mathrm{m}^{2} \mathrm{~K}$, the SHGC was 0.583 , and the Tvis (Visible transmittance) was 0.647 .

Table 2. Analysis results for optical and thermal properties of the glazing and frame of existing old curtain walls.

\begin{tabular}{|c|c|c|c|c|c|}
\hline \multicolumn{2}{|c|}{ Division } & \multicolumn{2}{|c|}{ U-Value $\left(\mathrm{W} / \mathrm{m}^{2} \mathrm{~K}\right)$} & $\begin{array}{c}\text { Solar Heat Gain } \\
\text { Coefficient (SHGC) }\end{array}$ & Tvis \\
\hline \multicolumn{2}{|c|}{ Double glazing } & \multicolumn{2}{|c|}{2.813} & 0.697 & 0.771 \\
\hline \multirow{8}{*}{$\begin{array}{l}\text { Curtain wall } \\
\text { Frame }\end{array}$} & \multirow{2}{*}{ Head } & Frame & 8.570 & & \\
\hline & & Edge & 2.934 & & \\
\hline & \multirow{2}{*}{ Divider } & Frame & 8.811 & & \\
\hline & & Edge & 2.985 & & \\
\hline & \multirow{2}{*}{ Sill } & Frame & 8.816 & & \\
\hline & & Edge & 2.985 & & \\
\hline & \multirow{2}{*}{ Jamb } & Frame & 10.605 & & \\
\hline & & Edge & 2.861 & & \\
\hline
\end{tabular}

Table 3. Optical and thermal properties of the existing old curtain wall system.

\begin{tabular}{cccc}
\hline Division & U-Value $\left(\mathbf{W} / \mathbf{m}^{2} \mathbf{K}\right)$ & SHGC & Tvis \\
\hline Curtain wall system & 3.806 & 0.583 & 0.647 \\
\hline
\end{tabular}

Figure 4 shows the two remodeling methods using PDLC films proposed in this study, which can improve the performance of the existing old curtain wall system described above. The first method is to attach PDLC films to the double glazing of existing old curtain walls. It lowers the cooling load by decreasing the SHGC and can control transmittance according to the external environment. The second method is to configure a frame separately from the laminated glass with a PDLC film between two glass substrates and to attach a new window to the indoor side. It can not only control solar radiation but also can reinforce insulation by installing an additional window.

a) PDLC Film

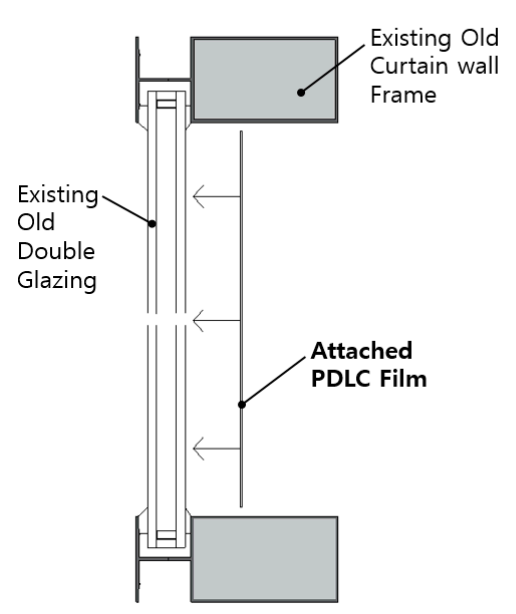

b) PDLC Window

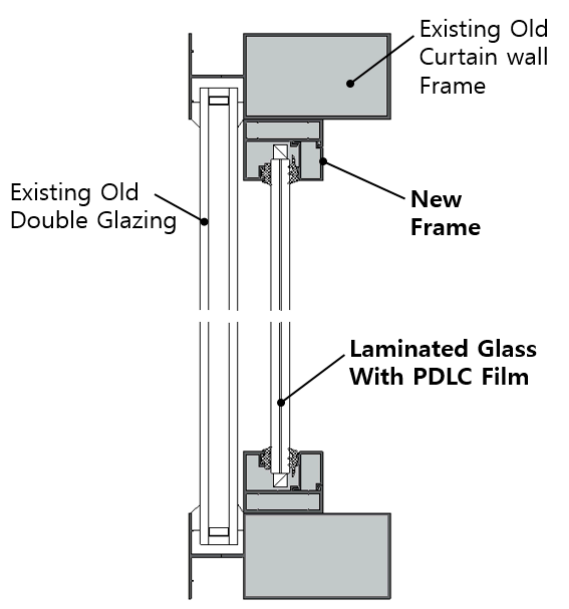

Figure 4. Old window remodeling method using PDLC film.

However, a disadvantage is reducing glazing area because an added retrofit frame must be installed to apply the PDLC window. The height of this frame is $43 \mathrm{~mm}$. Thus, the edge part of the glazing area of the existing curtainwall is hidden by $43 \mathrm{~mm}$. This study focuses on remodeling methods 
using PDLC films while leaving the existing glass as is. Another possible alternative is to remove the existing glass and apply a PDLC laminated glass. We will address the method of applying a new PDLC laminated glass in a follow-up study.

\subsection{Optical and Thermal Properties According to the Application of Attached Remodeling PDLC Film}

This section examines the changes in the optical and thermal properties of curtain walls when the PDLC film is directly attached to the indoor-side glass of the existing old curtain wall by the first remodeling method as shown in Figure 4a in Section 3.1. The analysis was conducted as follows: The optical properties (reflectance, transmittance, emissivity) of the single glazing with a PDLC film were analyzed using Optic 6 and those of double glazing were analyzed using Window 7.4. Then the optical and thermal properties (U-value, SHGC, Tvis) were compared with those of double glazing applied to the existing old curtain walls. Finally, the optical and thermal properties were compared using Window 7.4 between the existing old curtain wall system with integrated double glazing and frame and the curtain wall system with a PDLC film.

In the first step, the four types of PDLC films derived in Section 2 were set as applied films using the Optic 6 program, and then a PDLC film was attached to a $6 \mathrm{~mm}$ clear glass (IGDB No. 13503) used in the old curtain wall described in Section 3.1.

Table 4 outlines the optical properties of the single glazing with a PDLC film. As shown in Table 5, the solar and visible light transmittance decreased in general when the PDLC film was attached relative to the existing $6 \mathrm{~mm}$ clear glass. Based on the OFF state for blocking sunlight, the solar transmittance was 0.211 for A type, and gradually increased to $0.352,0.416$, and 0.650 for types $\mathrm{B}, \mathrm{C}$, and $\mathrm{D}$, respectively. The transmittance variation range of the solar transmittance was $0.039,0.050$, 0.150 , and 0.087 for types A, B, C, and D, respectively. Hence, as with the optical properties, type C showed the largest transmittance variation range, followed by types $\mathrm{D}, \mathrm{B}$, and $\mathrm{A}$.

Table 4. Optical properties of single glazing with a PDLC film.

\begin{tabular}{|c|c|c|c|c|c|c|c|c|c|c|}
\hline \multirow{3}{*}{ Division } & & \multirow{3}{*}{$\begin{array}{c}6 \mathrm{~mm} \text { Clear } \\
\text { Glass }\end{array}$} & \multicolumn{8}{|c|}{ Existing 6 mm Clear Glass + PDLC Film } \\
\hline & & & \multicolumn{2}{|c|}{ A Type } & \multicolumn{2}{|c|}{ B Type } & \multicolumn{2}{|c|}{ C Type } & \multicolumn{2}{|c|}{ D Type } \\
\hline & & & On & Off & On & Off & On & Off & On & Off \\
\hline $\begin{array}{c}\text { Solar } \\
\text { Transmittance }\end{array}$ & & 0.765 & 0.250 & 0.211 & 0.402 & 0.352 & 0.566 & 0.416 & 0.737 & 0.650 \\
\hline Solar & front & 0.073 & 0.438 & 0.432 & 0.359 & 0.375 & 0.099 & 0.134 & 0.101 & 0.142 \\
\hline Reflectance & back & 0.073 & 0.561 & 0.552 & 0.420 & 0.390 & 0.113 & 0.153 & 0.107 & 0.160 \\
\hline $\begin{array}{c}\text { Visible } \\
\text { Transmittance }\end{array}$ & & 0.878 & 0.447 & 0.379 & 0.621 & 0.536 & 0.622 & 0.416 & 0.844 & 0.730 \\
\hline Visible & front & 0.083 & 0.380 & 0.379 & 0.280 & 0.316 & 0.108 & 0.167 & 0.113 & 0.181 \\
\hline Reflectance & back & 0.083 & 0.399 & 0.397 & 0.262 & 0.270 & 0.126 & 0.187 & 0.114 & 0.186 \\
\hline \multirow{2}{*}{ Emissivity } & front & 0.837 & 0.837 & 0.837 & 0.837 & 0.837 & 0.837 & 0.837 & 0.837 & 0.837 \\
\hline & back & 0.837 & 0.767 & 0.767 & 0.767 & 0.767 & 0.767 & 0.767 & 0.767 & 0.767 \\
\hline
\end{tabular}

Table 5. Optical and thermal properties of double glazing with a PDLC film.

\begin{tabular}{|c|c|c|c|c|c|c|c|c|c|}
\hline \multirow{3}{*}{ Division } & \multirow{3}{*}{$\begin{array}{c}26 \mathrm{~mm} \\
\text { Double } \\
\text { Glazing }\end{array}$} & \multicolumn{8}{|c|}{ Existing Double Glazing + PDLC Film } \\
\hline & & \multicolumn{2}{|c|}{ A Type } & \multicolumn{2}{|c|}{ B Type } & \multicolumn{2}{|c|}{ C Type } & \multicolumn{2}{|c|}{ D Type } \\
\hline & & On & Off & On & Off & On & Off & On & Off \\
\hline U-Value $\left(\mathrm{W} / \mathrm{m}^{2} \mathrm{~K}\right)$ & 2.813 & 2.811 & 2.811 & 2.811 & 2.811 & 2.811 & 2.811 & 2.811 & 2.811 \\
\hline SHGC & 0.697 & 0.475 & 0.402 & 0.498 & 0.470 & 0.633 & 0.567 & 0.680 & 0.633 \\
\hline Tvis & 0.771 & 0.408 & 0.346 & 0.563 & 0.487 & 0.555 & 0.373 & 0.747 & 0.650 \\
\hline
\end{tabular}

In the second step, double glazing ( $6 \mathrm{~mm}$ clear $+14 \mathrm{~mm}$ air $+6 \mathrm{~mm}$ glass with PDLC film) were set up using Window 7.4 program from single glazing with four types of PDLC films, and their optical 
and thermal properties were analyzed. Table 5 outlines the analysis result data. When the PDLC film was attached, the heat transmission rate changed very little by $0.02 \mathrm{~W} / \mathrm{m}^{2} \mathrm{~K}$, but solar heat gain coefficient and visible light transmittance decreased.

In the third step, double glazing with four types of PDLC film was applied to the old curtain wall frame using the Therm 7.4 program, and then, their frame heat transmission rates were calculated. In the last step, the optical and thermal properties of the $2 \mathrm{~m} \times 2 \mathrm{~m}$ curtain wall system were derived using the Window 7.4 program. Table 6 compares the optical and thermal properties data between the old curtain wall system and the curtain wall systems with four types of PDLC films. As can be seen, the attachment of the PDLC film did not have a significant effect on the insulation performance of the curtain wall system, but SHGC generally decreased. Therefore, it is expected to have an energy reduction effect when applied to an office building with a large cooling load. The building energy performance improvement effect of the PDLC film based on the data in this section is analyzed in detail in Section 4.

Table 6. Optical and thermal properties of curtain wall system with a PDLC film

\begin{tabular}{|c|c|c|c|c|c|c|c|c|c|}
\hline \multirow{3}{*}{ Division } & \multirow{3}{*}{$\begin{array}{l}\text { Existing Old } \\
\text { Curtain Wall }\end{array}$} & \multicolumn{8}{|c|}{ Existing Old Curtain Wall + PDLC Film } \\
\hline & & \multicolumn{2}{|c|}{ A Type } & \multicolumn{2}{|c|}{ B Type } & \multicolumn{2}{|c|}{ C Type } & \multicolumn{2}{|c|}{ D Type } \\
\hline & & On & Off & On & Off & On & Off & On & Off \\
\hline U-Value $\left(\mathrm{W} / \mathrm{m}^{2} \mathrm{~K}\right)$ & 3.806 & 3.802 & 3.802 & 3.802 & 3.802 & 3.802 & 3.802 & 3.802 & 3.802 \\
\hline SHGC & 0.583 & 0.343 & 0.333 & 0.415 & 0.392 & 0.527 & 0.519 & 0.569 & 0.528 \\
\hline Tvis & 0.647 & 0.343 & 0.290 & 0.472 & 0.409 & 0.466 & 0.389 & 0.627 & 0.545 \\
\hline
\end{tabular}

\subsection{Optical and Thermal Properties According to the Application of PDLC Laminated Glass}

In this section, the changes in the optical and thermal properties of the curtain wall are examined when the PDLC laminated glass is attached to the existing old curtain walls in the second remodeling method as shown in Figure $4 \mathrm{~b}$ in Section 3.1.

Firstly, the four types of PDLC films derived in Section 2 were set as interlayers by using the Optic 6 program, which were then laminated between two sheets of $6 \mathrm{~mm}$ clear glass. Secondly, the optical and thermal properties when the PDLC laminated glass derived using Optic 6 was added to the existing double glazing were analyzed using the Window 7.4 program. Table 7 outlines the analysis results. The heat transmission rate changed from 2.813 to $1.758 \mathrm{~W} / \mathrm{m}^{2} \mathrm{~K}$, showing an improvement in the insulation performance by $37.5 \%$. The SHGC decreased from 0.697 to a range of $0.536-0.584$, but the difference in SHGC by film type was not larger than that of the method described in Section 3.2 where the PDLC film was attached to the double glazing. This seems to be an effect of the stagnant air layer of $23.1 \mathrm{~mm}$ between the existing double glazing and the PDLC laminated glass. Furthermore, the variation range of SHGC by ON/OFF and the visible light transmittance were smaller than those of the method in Section 3.2 where the PDLC film was directly attached to the existing double glazing.

Table 7. Optical and thermal properties according to the addition of a PDLC laminated glass to the existing double glazing.

\begin{tabular}{|c|c|c|c|c|c|c|c|c|c|}
\hline \multirow{3}{*}{ Division } & \multirow{3}{*}{ 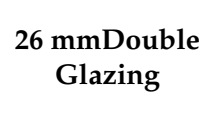 } & \multicolumn{8}{|c|}{ Existing Double Glazing + PDLC Window } \\
\hline & & \multicolumn{2}{|c|}{ A Type } & \multicolumn{2}{|c|}{ B Type } & \multicolumn{2}{|c|}{ C Type } & \multicolumn{2}{|c|}{ D Type } \\
\hline & & On & Off & On & Off & On & Off & On & Off \\
\hline U-Value $\left(\mathrm{W} / \mathrm{m}^{2} \mathrm{~K}\right)$ & 2.813 & 1.758 & 1.758 & 1.758 & 1.758 & 1.758 & 1.758 & 1.758 & 1.758 \\
\hline SHGC & 0.697 & 0.541 & 0.536 & 0.557 & 0.551 & 0.566 & 0.549 & 0.584 & 0.575 \\
\hline Tvis & 0.771 & 0.301 & 0.255 & 0.418 & 0.361 & 0.419 & 0.280 & 0.570 & 0.492 \\
\hline
\end{tabular}

Thirdly, the variation in the insulation performance of the frame and edge when a PDLC window was applied to the existing old curtain wall using the Therm 7.4 program was analyzed. Table 8 outlines the heat transmission rates of the frame parts of the existing curtain wall. Because no thermal bridging 
insulation material was applied to the frame, the heat transmission rate was $8.570-10.602 \mathrm{~W} / \mathrm{m}^{2} \mathrm{~K}$ in the frame part and $2.561-2.685 \mathrm{~W} / \mathrm{m}^{2} \mathrm{~K}$ in the edge part, indicating a very low insulation performance.

Table 8. Analysis results for the thermal properties of the frame parts of the existing old curtain wall.

\begin{tabular}{|c|c|c|c|c|}
\hline Division & Head & Jamb & Sill & Divider \\
\hline $\begin{array}{l}\text { Existing old } \\
\text { curtain wall }\end{array}$ & & & & \\
\hline Frame U-value & 8.570 & 8.811 & 8.816 & 10.605 \\
\hline Edge U-value & 2.934 & 2.985 & 2.985 & 2.861 \\
\hline
\end{tabular}

A PDLC laminated glass was applied as an additional window to the existing curtain wall as shown in Table 9, and the heat transmission rate was analyzed. The analysis result showed that the insulation performances of the frame and edge greatly increased. In particular, the insulation performance of the divider part significantly improved by $61.9 \%$ from 10.605 to 4.043 . There are various factors affecting the U-values of the edge and frame, including the frame shape, frame material (polyamide, polyurethane), spacer material, thickness of air layer between glasses, and the composition of this layer (argon, air). In this study, it is considered that the addition of the layer of air by the addition of laminated PDLC glass to the existing double glazing affected the improvement in the heat transmission rate of the frame and edge of the indoor-side glass. Thermal breaking materials (polyamide and polyurethane) were not applied to the frame for economic efficiency; however, applying such materials to the frame for remodeling can further improve the insulation performance.

Table 9. Analysis results for the thermal properties of the curtain wall frame with PDLC window.

\begin{tabular}{|c|c|c|c|c|}
\hline Division & Head & Jamb & Sill & Divider \\
\hline $\begin{array}{c}\text { Remodeling } \\
\text { curtain wall with } \\
\text { PDLC } \\
\text { laminated glass }\end{array}$ & & & & \\
\hline Frame U-value & 5.770 & 6.133 & 6.134 & 4.043 \\
\hline Edge U-value & 2.121 & 2.022 & 2.022 & 2.083 \\
\hline
\end{tabular}

Finally, the optical and thermal properties of the curtain wall system with a PDLC laminated glass window were analyzed using the Window 7.4 program. The analysis results revealed that, as shown in Table 10, the U-value improved by $23.4 \%$ from 3.806 to $2.915 \mathrm{~W} / \mathrm{m}^{2} \mathrm{~K}$ by the application of the PDLC laminated glass window to the existing curtain wall system. Even though the SHGC and visible 
light transmittance decreased compared with the existing curtain wall and the PDLC film attachment method described in Section 3.2, the PDLC window application method showed a smaller variation range of transmittance than the PDLC film attachment method.

Table 10. Optical and thermal properties of the curtain wall system with PDLC window.

\begin{tabular}{|c|c|c|c|c|c|c|c|c|c|}
\hline \multirow{3}{*}{ Division } & \multirow{3}{*}{$\begin{array}{l}\text { Existing Old } \\
\text { Curtain Wall }\end{array}$} & \multicolumn{8}{|c|}{ Existing Old Curtain Wall + PDLC Window } \\
\hline & & \multicolumn{2}{|c|}{ A Type } & \multicolumn{2}{|c|}{ B Type } & \multicolumn{2}{|c|}{ C Type } & \multicolumn{2}{|c|}{ D Type } \\
\hline & & On & Off & On & Off & On & Off & On & Off \\
\hline $\begin{array}{l}\text { U-Value } \\
\left(\mathrm{W} / \mathrm{m}^{2} \mathrm{~K}\right)\end{array}$ & 3.806 & 2.915 & 2.915 & 2.915 & 2.195 & 2.915 & 2.915 & 2.915 & 2.915 \\
\hline SHGC & 0.583 & 0.369 & 0.365 & 0.381 & 0.376 & 0.387 & 0.375 & 0.400 & 0.393 \\
\hline Tvis & 0.647 & 0.207 & 0.175 & 0.288 & 0.248 & 0.288 & 0.193 & 0.392 & 0.339 \\
\hline
\end{tabular}

Sections 3.2 and 3.3 presented an analysis of the remodeling method of the old curtain wall system using a PDLC film. Based on this data, Section 4 demonstrates the energy reduction and building environment improvement effects analyzed through a building energy analysis simulation.

\section{Analytical Simulation Model for Building Energy Performance Evaluation}

\subsection{Overview of the Analytical Simulation Model}

In this section, the possibility of improving the building energy and daylight performance by remodeling methods using PDLC films is analyzed for old office buildings with a curtain wall envelope. As described in Section 3, the two remodeling methods are as follows: The first is to attach a PDLC film to the indoor side of the existing curtain wall glazing, and the second method is to laminate a PDLC film between two sheets of glass and then configure and attach a window with a separate frame.

In this study, EnergyPlus 8.5 developed by the U.S. Department of Energy was used as a simulation tool. EnergyPlus can facilitate the building energy analysis for smart windows such as PDLC films because it provides switchable glazing components that can control the transmittance of glass according to the changes in indoor and outdoor environment [38-43]. Furthermore, EnergyPlus can analyze the glare reduction performance by PDLC film application because it provides components to enable analysis of the glare of window surfaces by using the Daylight Glare Index (DGI) developed by Hopkinson [44]. EnergyPlus 8.5 also has the advantage of evaluating the appropriate indoor illuminance by natural light because it can analyze indoor light environment through a daylight sensor [45].

Figure 5 shows the analysis model and building elevation for simulation. As shown in the plan on the left in Figure 5, the floor area of the analysis model was set to $50 \mathrm{~m} \times 50 \mathrm{~m}$, the story height to $3 \mathrm{~m}$, and the window area ratio to $60 \%$. The plan is divided into a core zone and perimeter zones. The analysis in this study focused on the south, east, and west perimeter zones, which are affected by solar radiation. The right side of Figure 5 shows the EnergyPlus 8.5 analysis model using OpenStudio, modeling a three-floor office building, and the middle layer was analyzed.

Figure 6 shows the elevation of the analysis model, which largely consists of a wall area, spandrel area, and vision area. The vision area accounts for $60 \%$ of the elevation, and the interval between vertical members was assumed to be $1.2 \mathrm{~m}$. The intervals for horizontal members were set to $1.3 \mathrm{~m}$ for the top members and $0.7 \mathrm{~m}$ for the bottom members.

For the glazing and frame properties of the old curtain wall applied to the vision area, the optical and thermal properties of the double glazing and frame derived using LBNL's Window 7.4 and Therm 7.4 in Section 3.1 were applied. Table 11 outlines the glazing and frame properties of the vision area input to EnergyPlus 8.5. The Therm 7.4 program calculates the heat transmission rates of the frame separately for head, jamb, and sill. However, the average value was applied in EnergyPlus 8.5, which requires a single value for the frame. In Table 11, when the ratios of frame-edge glass conductance 
to center of glass conductance of the frame and divider were input, the average frame-edge glass conductance value was calculated for the head, jamb, and sill parts.
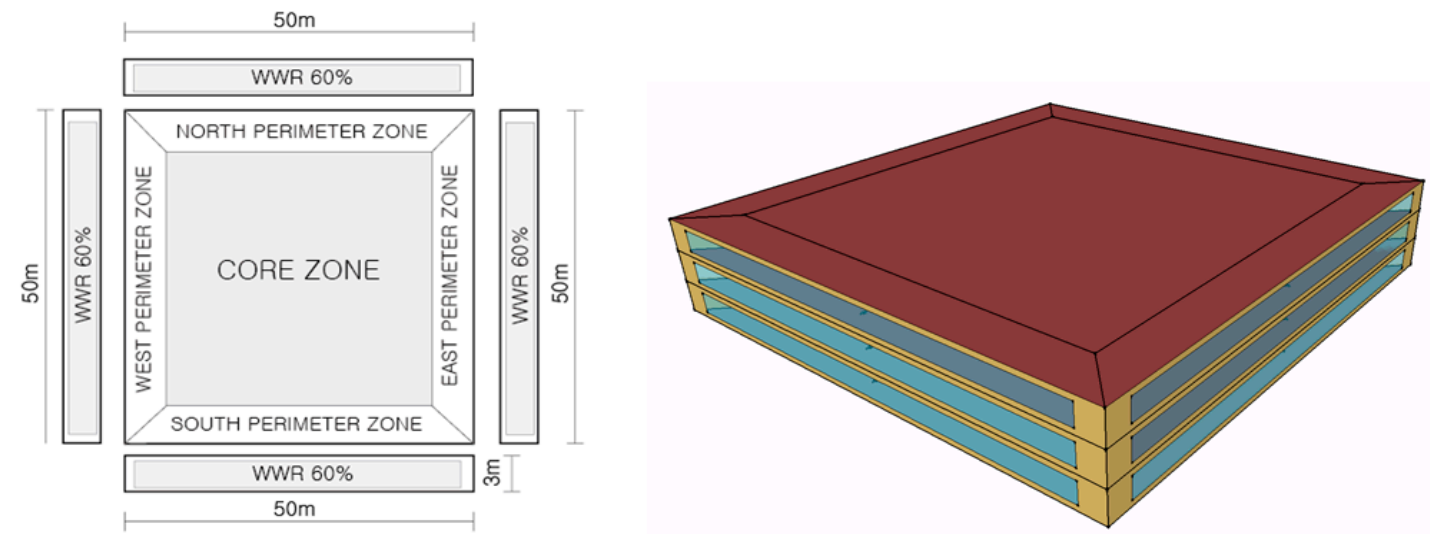

Figure 5. Analysis model plan (left) and EnergyPlus 8.5 simulation analysis model (right).

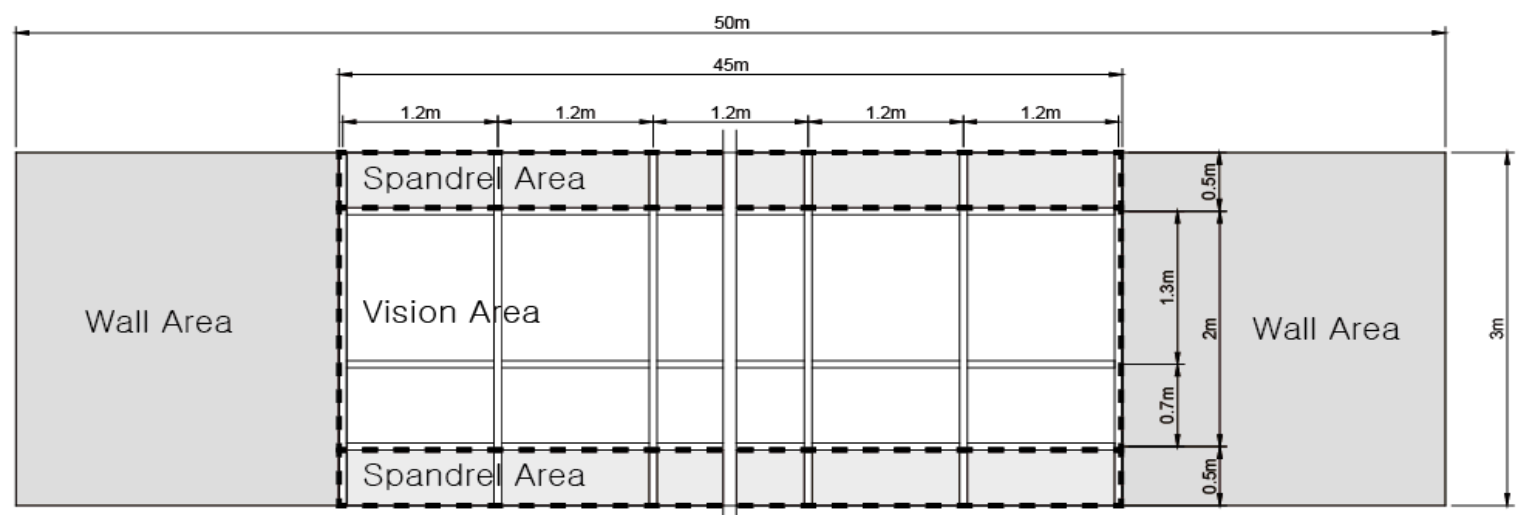

Figure 6. Detailed elevation of the analysis model.

Table 11. Optical and thermal properties of the analysis model's old curtain wall.

\begin{tabular}{|c|c|c|}
\hline \multicolumn{2}{|c|}{ Division } & \multirow{2}{*}{$\begin{array}{c}\text { Properties } \\
0.697\end{array}$} \\
\hline $26 \mathrm{~mm}$ double glazing & SHGC & \\
\hline$(6 \mathrm{~mm}$ clear glass +14 air $+6 \mathrm{~mm}$ & Tvis & 0.771 \\
\hline clear glass) & Conductance & $2.813 \mathrm{~W} / \mathrm{m}^{2} \mathrm{~K}$ \\
\hline \multirow{5}{*}{$\begin{array}{c}\text { Frame } \\
\text { (head, jamb, sill) }\end{array}$} & Width & $60 \mathrm{~mm}$ \\
\hline & Outside projection & $6 \mathrm{~mm}$ \\
\hline & Inside projection & $106 \mathrm{~mm}$ \\
\hline & Conductance & $8.732 \mathrm{~W} / \mathrm{m}^{2} \mathrm{~K}$ \\
\hline & $\begin{array}{l}\text { Ratio of frame-edge glass conductance to } \\
\text { center of glass conductance }\end{array}$ & 1.055 \\
\hline \multirow{5}{*}{ Divider } & Width & $60 \mathrm{~mm}$ \\
\hline & Outside projection & $6 \mathrm{~mm}$ \\
\hline & Inside projection & $106 \mathrm{~mm}$ \\
\hline & Conductance & $10.605 \mathrm{~W} / \mathrm{m}^{2} \mathrm{~K}$ \\
\hline & $\begin{array}{l}\text { Ratio of frame-edge glass conductance to } \\
\text { center of glass conductance }\end{array}$ & 1.102 \\
\hline
\end{tabular}

Table 12 shows the wall and spandrel areas corresponding to the exterior wall of the analysis model. They were configured in accordance with the insulation standards of the Building Energy Saving Design Standard of South Korea (2008) [46]. The insulator used in this study is expanded polystyrene (EPS) with a thermal conductivity of $0.034 \mathrm{~W} / \mathrm{mK}$. South Korea established regulations for 
the minimum performance of insulation materials for exterior wall to improve the building energy efficiency on January 1, 2008. Accordingly, this study assumed and applied the exterior wall (wall, spandrel) insulation standards corresponding to the time when the energy saving design standards of buildings were established in South Korea as the insulation performance of old buildings.

Table 12. Thermal properties of the exterior wall of the analysis model.

\begin{tabular}{ccc}
\hline Division & Materials & Properties \\
\hline \multirow{2}{*}{ Exterior wall } & $200 \mathrm{~mm}$ concrete & $\mathrm{U}$-value \\
& $65 \mathrm{~mm}$ insulation & $0.280 \mathrm{~W} / \mathrm{m}^{2} \mathrm{~K}$ \\
& $19 \mathrm{~mm}$ gypsum board & \\
Spandrel & $26 \mathrm{~mm}$ double glazing & $\mathrm{U}$-value \\
& Spandrel air space & $0.422 \mathrm{~W} / \mathrm{m}^{2} \mathrm{~K}$ \\
& $65 \mathrm{~mm}$ insulation & \\
\hline \multirow{2}{*}{ Exterior Floor } & $19 \mathrm{~mm}$ gypsum board & $\mathrm{U}$-value \\
& $75 \mathrm{~mm}$ insulation & $0.418 \mathrm{~W} / \mathrm{m}^{2} \mathrm{~K}$ \\
\hline \multirow{2}{*}{ Exterior Roof } & $200 \mathrm{~mm}$ concrete & $\mathrm{U}$-value \\
& $100 \mathrm{~mm}$ concrete & $0.253 \mathrm{~W} / \mathrm{m}^{2} \mathrm{~K}$ \\
& $110 \mathrm{~mm}$ insulation & \\
\hline
\end{tabular}

The temperatures of the analysis model were set to $20{ }^{\circ} \mathrm{C}$ and $26{ }^{\circ} \mathrm{C}$ according to the indoor temperature standards for capacity calculation of cooling and heating systems on the Building Energy Saving Design Standards. For heating, ventilation, and air conditioning (HVAC), the IdealLoadsAirSystem provided by EnergyPlus was applied for load analysis excluding the interferences of system variables to the maximum.

For internal heat acquisition, an overhead lighting of $10.8 \mathrm{~W} / \mathrm{m}^{2}$, a peak occupancy of 22.3 $\mathrm{m}^{2} /$ person, and equipment of $8.6 \mathrm{~W} / \mathrm{m}^{2}$ were applied in accordance with the standards of ASHRAE (American society of heating, refrigerating and air-conditioning engineers) Fundamentals (2009) [47]. For the internal heat acquisition schedule of human body, lighting, and devices, the Office Schedule in the Schedules of DataSets in EnergyPlus was applied. For the outside air intake, $1.1 \mathrm{~m}^{3} / \mathrm{m}^{2} \mathrm{~h}$ was applied in accordance with the operation regulations of the building energy efficiency grade certification system.

For the weather data, the weather data of the Incheon region on the EnergyPlus website were used. The climatic conditions of the Incheon region are characterized by continental climate where summer and winter coexist with a cold high pressure of the continent in winter, high temperature and humidity of the oceanic air mass in summer, and an annual temperature difference of $30^{\circ} \mathrm{C}$.

\subsection{PDLC Control Condition}

The film-attached PDLC and the added PDLC window have differences in remodeling methods, but both require the ON/OFF control of PDLC. The PDLC control methods can be divided into manual control by user and automatic control by the external environment. The variables for automatic control include outdoor temperature, indoor temperature, external solar radiation, and external illuminance. From the user's point of view, the purpose of shading devices such as PDLC is to prevent glare. Therefore, in this study, the solar radiation was blocked by turning the PDLC off when glare occurred on the window surface.

EnergyPlus 8.5 provides a switchable glazing component for smart window control such as PDLC and allows various control type settings. Among the control types, this study assumed the OnIfHighGlare type, which is controlled by DGI developed by Hopkinson. As shown in Table 13, it is recommended that DGI should be below a proper value depending on the use of the room. In the 
case of office building such as the analysis model in this study, a DGI of 22 or lower is recommended. Therefore, the PDLC was set to turn off when the DGI became 22.

Table 13. Hopkinson's recommended values for the Daylight Glare Index (DGI) by use [48].

\begin{tabular}{cc}
\hline Division & Recommended Value \\
\hline Art galleries & 16 \\
\hline Hospital wards & 18 \\
\hline Museums, School classroom & 20 \\
\hline Laboratories, Offices & 22 \\
\hline
\end{tabular}

For the DGI, a reference point for detecting discomfort glare is set and the degree of glare by the luminance difference between window surface and interior surface when the window surface is viewed from the reference point is calculated using Equation (1). Figure 7 describes the location of the reference point applied to the analysis model in this study.

$$
\mathrm{G}=\frac{L_{\omega}^{1.6} \Omega^{0.8}}{L_{b}+0.07 \omega^{0.5} L_{\omega}}
$$

where, $\mathrm{G}$ is the discomfort glare constant, $L_{\omega}$ is the average luminance of the window as seen from the reference point, $\omega$ is the solid angle subtended by window, modified to take direction of occupant view into account, and $L_{b}$ is the luminance of the background area surrounding the window.

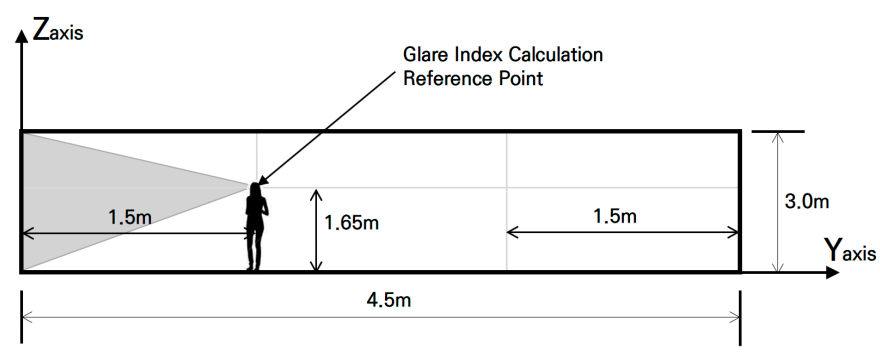

Figure 7. Reference point for DGI analysis of the analysis model.

\section{Results and Discussion}

\subsection{Building Energy Performance Evaluation Result According to Glass-Attached PDLC film Remodeling}

In this section, building energy consumption is analyzed for the first remodeling method, i.e., attaching a PDLC film directly to the curtain walls of existing old office buildings. For the properties of the PDLC film applied in this analysis, the optical and thermal properties derived in Section 3.2 were applied. For control conditions, as mentioned in Section 4.2, PDLC film was set to turn OFF when the DGI detected at the reference point reached 22 .

In this study, the baseline was established on the basis of the energy consumption of an office building with existing old curtain walls and the building energy performance was analyzed according to the PDLC film application. First, to examine the building energy reduction performance according to the PDLC film application, as shown in Table 14, the building energy consumption could be reduced by $17.0 \%, 15.8 \%, 7.3 \%$, and $3.1 \%$ for types $\mathrm{A}, \mathrm{B}, \mathrm{C}$, and $\mathrm{D}$, respectively.

To examine the optical properties by PDLC film type derived in Section 3.2, the lower the SHGC value of the PDLC film was, the higher the energy reduction performance was. The cause of this can be confirmed by the energy consumption characteristics of the baseline existing old office building. For existing old office buildings, the annual heating energy is $14,525.7 \mathrm{kWh}(18.5 \%)$, the annual cooling energy is $44,600.8 \mathrm{kWh}(56.7 \%)$, and the annual lighting energy is $19,498.4 \mathrm{kWh}(24.8 \%)$. Hence, 
the energy consumption is characterized by the dominant cooling energy. This seems to be because the window area is large and the SHGC of the existing curtain wall is high, and this has a great effect on the cooling load resulting from the external solar radiation inflow. Therefore, when remodeling using a PDLC film, the low SHGC type has a great effect on energy reduction.

Table 14. Annual building energy analysis result according to glass-attached PDLC film remodeling.

\begin{tabular}{ccccc}
\hline Division & $\begin{array}{c}\text { Heating Energy } \\
\mathbf{( k W h )}\end{array}$ & $\begin{array}{c}\text { Cooling Energy } \\
\mathbf{( k W h )}\end{array}$ & $\begin{array}{c}\text { Total Energy } \\
\mathbf{( k W h )}\end{array}$ & Reducing Rate \\
\hline A type & $20,566.5$ & $28,484.9$ & $49,051.4$ & $-17.0 \%$ \\
\hline B type & $19,916.3$ & $29,872.4$ & $49,788.7$ & $-15.8 \%$ \\
\hline C type & $16,686.2$ & $38,099.9$ & $54,786.0$ & $-7.3 \%$ \\
\hline D type & $15,595.2$ & $41,694.8$ & $57,290.0$ & $-3.1 \%$ \\
\hline Baseline & $14,525.7$ & $44,600.8$ & $59,126.5$ & - \\
\hline
\end{tabular}

In this study, the PDLC film is turned OFF when discomfort glare occurs regardless of winter or summer conditions. Therefore, it can be seen that the heating energy increases through the application of PDLC film compared with that of the existing old curtain walls which maintain a transparent state in winter. To examine the heating and cooling energy consumption pattern in detail, the monthly energy consumption is shown as a graph in Figure 8. The graph shows that the heating energy consumption increases when the PDLC film for remodeling is applied in winter, and the type with a lower SHGC has greater heating energy consumption. However, applying the PDLC film for remodeling had a significant total energy reduction effect because of the large amount of cooling energy reduction. Therefore, PDLC film remodeling of office buildings with a high cooling energy ratio has an energy reduction effect and the lower the SHGC was, the higher the energy reduction performance was.

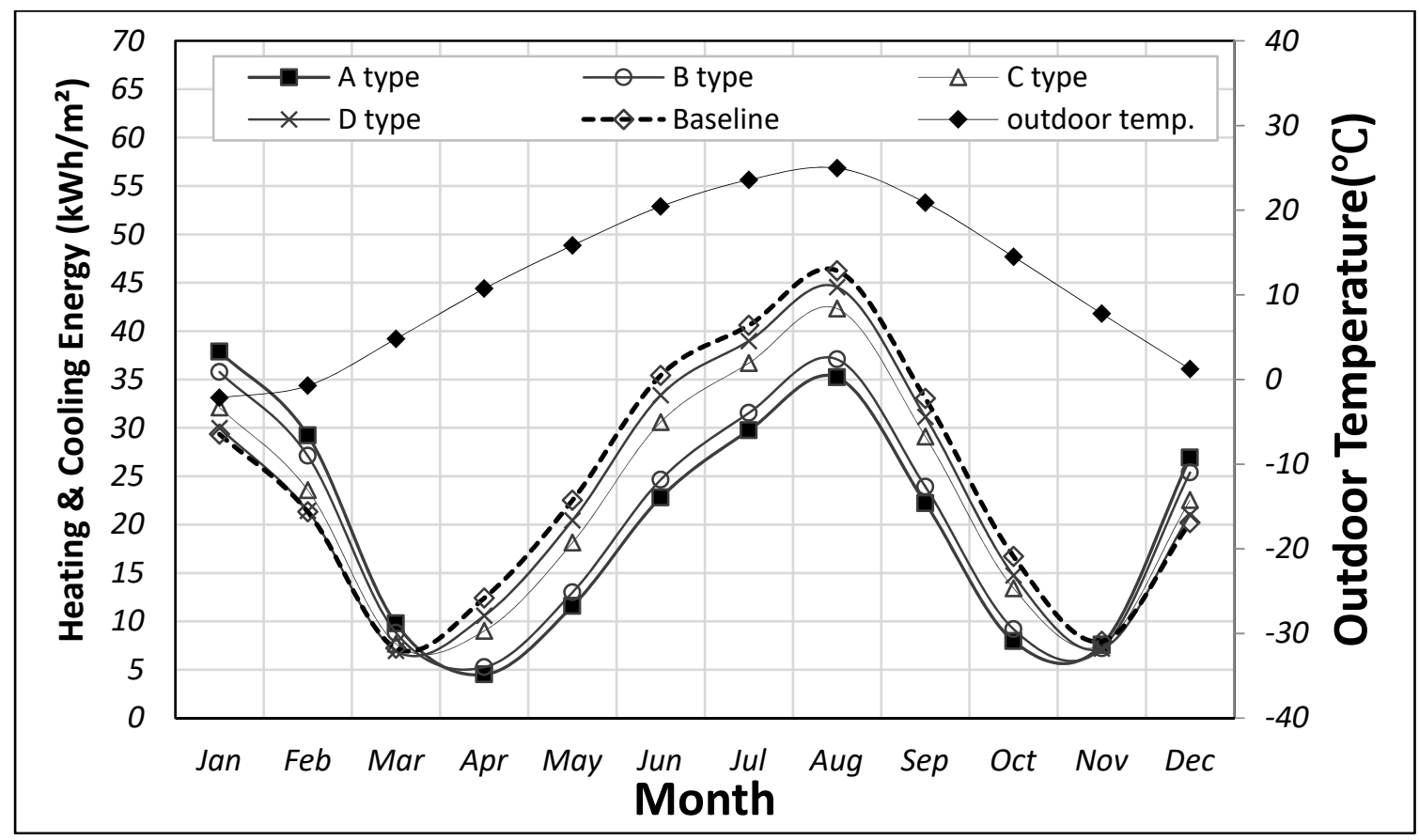

Figure 8. Analysis result of monthly heating and cooling energy consumption by PDLC film type. 


\subsection{Daylight Performance Evaluation Result According to Glass-Attached PDLC Film Remodeling}

In this section, daylight performance is examined through an analysis of the discomfort glare reduction performance and annual indoor appropriate illuminance ratio when the PDLC film was applied, i.e., for the first remodeling method.

First, the discomfort glare was analyzed. Figure 9 shows the scatter plots of the hourly daylight luminance data collected at the reference point to examine the glare reduction level relative to the baseline. The annual daylight luminance graph shows that the lower the visible light transmittance of the PDLC film was, the lower the annual average luminance was. To examine the data in the graphs, the baseline was $148,762.4 \mathrm{~cd} / \mathrm{m}^{2}$ by annual average. The annual average luminance was $64,007.4 \mathrm{~cd} / \mathrm{m}^{2}$, $89,881.2 \mathrm{~cd} / \mathrm{m}^{2}, 68,673.3 \mathrm{~cd} / \mathrm{m}^{2}$, and $124,067.3 \mathrm{~cd} / \mathrm{m}^{2}$ for types $\mathrm{A}, \mathrm{B}, \mathrm{C}$, and $\mathrm{D}$, respectively, which was lower than the baseline by $57.0 \%, 39.6 \%, 53.8 \%$, and $16.6 \%$, respectively.
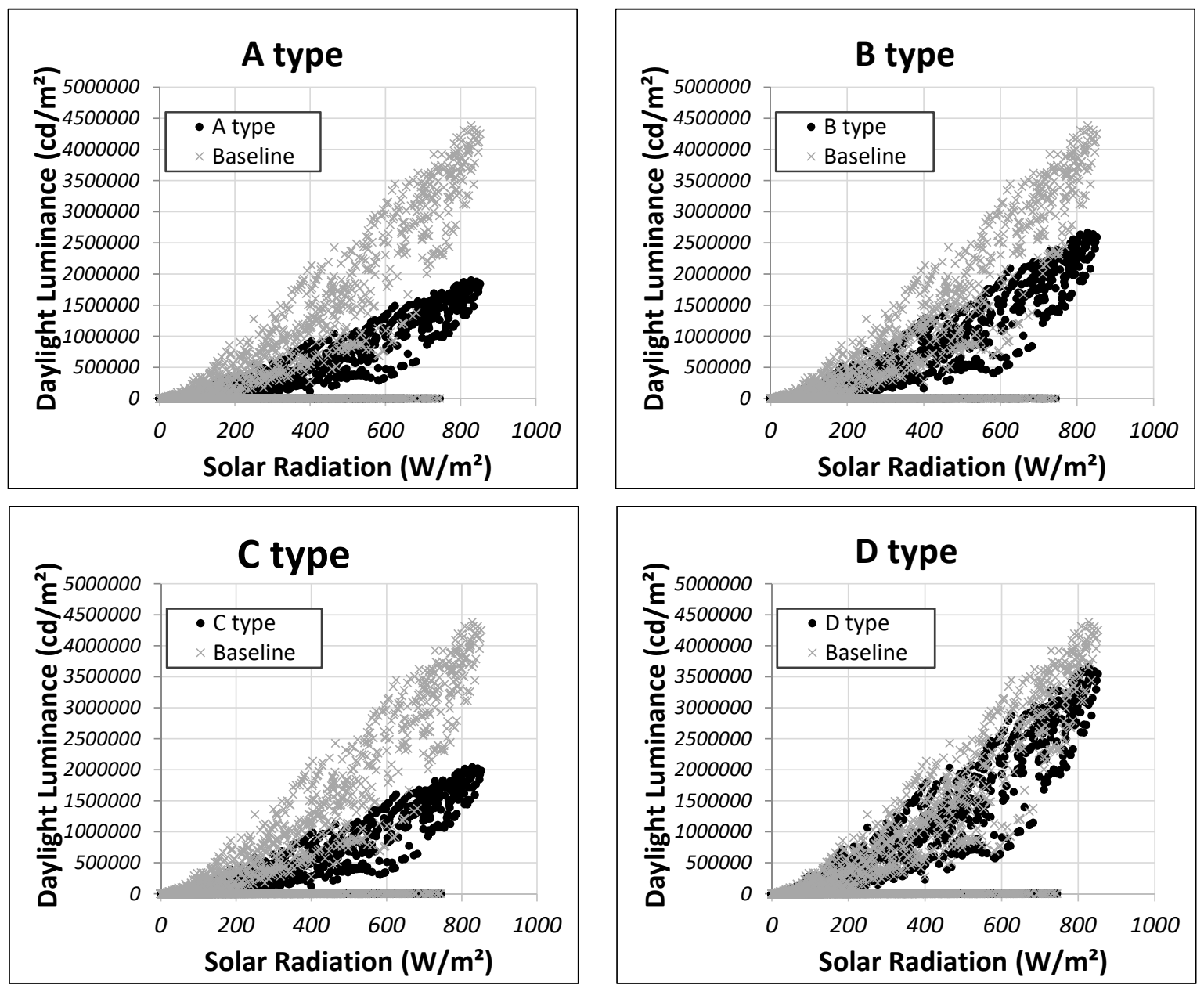

Figure 9. Analysis result of annual daylight luminance analysis by PDLC film type.

This result suggests that the visible light transmittance of the PDLC film had a dominant impact. In Section 3.2, the visible light transmittance in the OFF state when the PDLC film was attached to the existing old curtain wall was $0.290,0.409,0.389$, and 0.545 for types A, B C, and D, respectively. Hence, the transmittance increased in the ascending order of $A, C, B$, and $D$, as did the average luminance. Figure 10 shows graphs of the correlation between the annual average daylight luminance and the visible light transmittance and SHGC when the PDLC film was attached to the old curtain walls derived in Section 3.2. The coefficient of determination $\left(R^{2}\right)$ value shows that visible light transmittance had a significant effect on daylight luminance. 

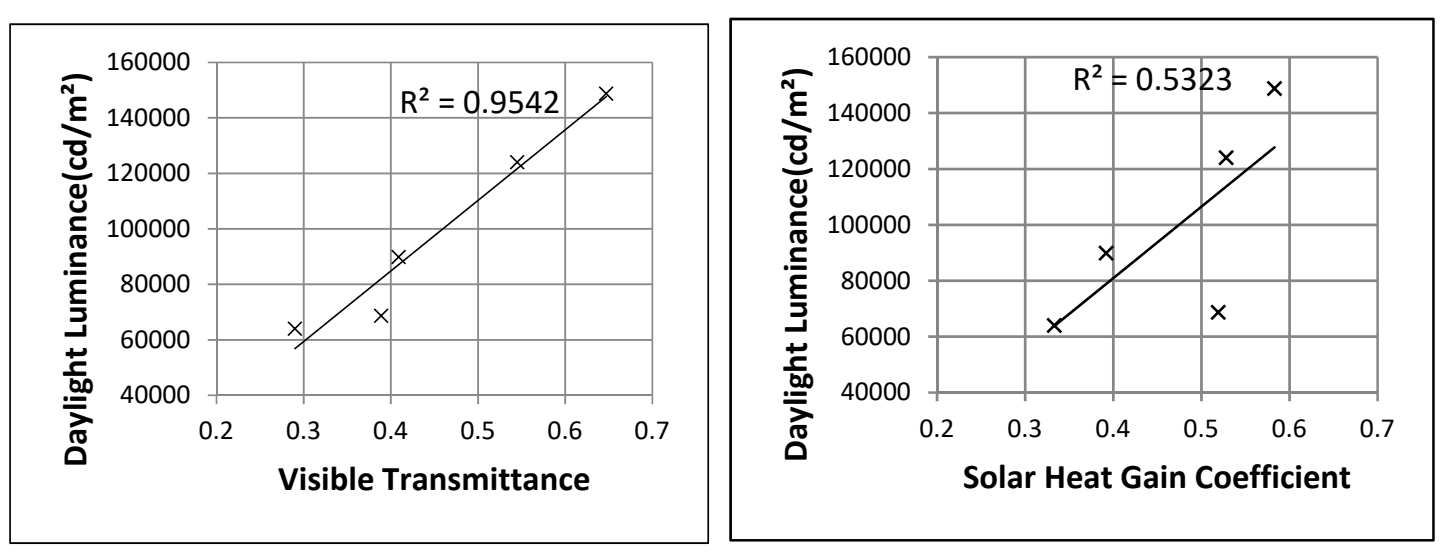

Figure 10. Correlations between visible light transmittance (left) and SHGC (right) and annual average daylight luminance.

For the second evaluation of daylight performance, DGI was analyzed. The time ratio corresponding to 22 or higher annual DGI was analyzed and the analysis results are shown in the left graph in Figure 11. For the existing old curtain walls, $42.7 \%$ time of the year, DGI was 22 or higher, thus requiring a separate shading device. Type $\mathrm{D}$ had a discomfort glare reduction effect, but it was insufficient for the work environment of users as discomfort glare occurred during $34.2 \%$ of the year. Types A, B, and C showed an improvement of more than $50 \%$ in comparison with the existing old curtain walls, and the discomfort glare occurred during $7.8 \%$, and $8.8 \%$ of the year for types $\mathrm{A}$ and $\mathrm{B}$, respectively. Hence, these two types demonstrated excellent performance in preventing glare.
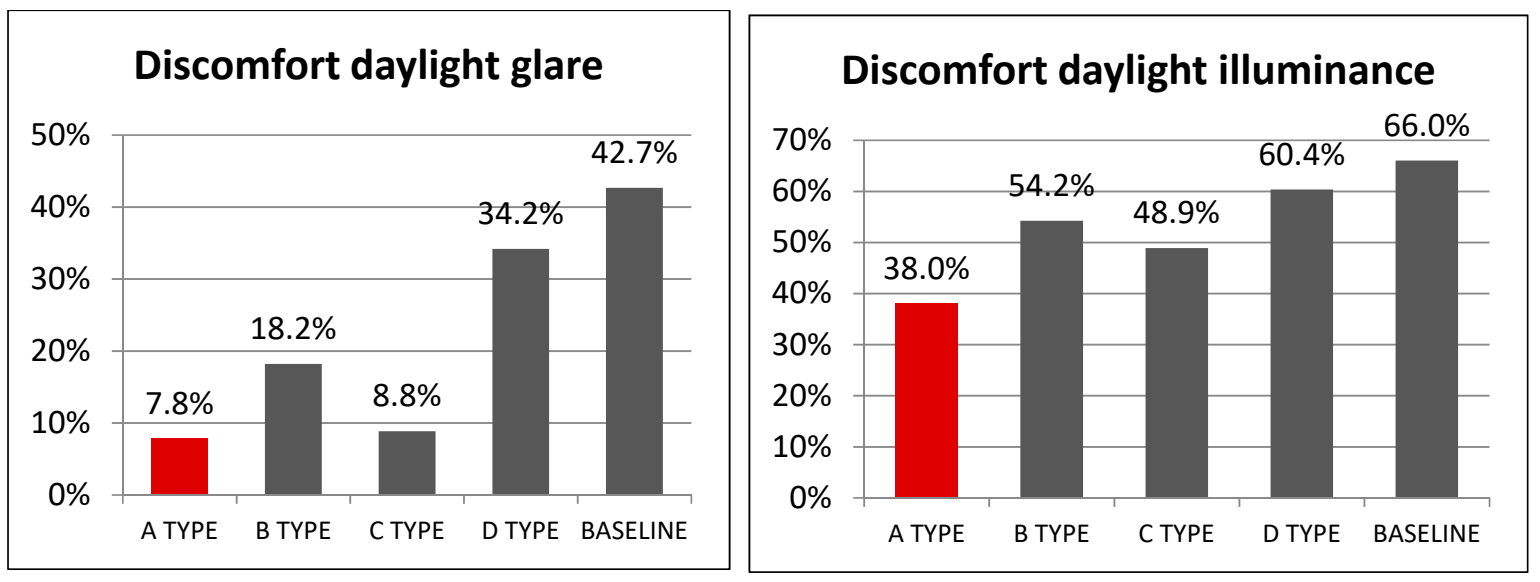

Figure 11. Annual time ratio of 22 or higher DGI (left) and annual time ratio of discomfort daylight illuminance (right).

The most important objective when using PDLC film is to prevent glare as a shading device; the application of PDLC films for types A and B was, therefore, appropriate. Visible light transmittance of less than $40 \%$ was effective when PDLC film remodeling was performed to prevent glare.

Next, the possibility of improving indoor illuminance performance by PDLC film remodeling was analyzed. For this analysis, the reference point for an indoor illuminance sensor was set in the EnergyPlus 8.5 analysis model, and the time corresponding to the annual appropriate illuminance range was analyzed by changing the PDLC film type. The criterion for the annual appropriate illuminance range for office buildings was set to 150-1500 lx in accordance with the KS A 3011 standard.

The graph on the right in Figure 11 shows the ratio of time in a year when the annual illuminance did not correspond to $150-1500$ lx. For the existing old curtain walls, $66 \%$ of the year corresponded to the discomfort daylight illuminance range, indicating a poor daylight performance. The annual proper indoor illuminance analysis result also showed a similar pattern as DGI. Type A showed the lowest 
annual discomfort daylight illuminance ratio of $38 \%$, indicating the best performance, followed by types $C, B$, and D.

To summarize the daylight performance analysis result, the lower the visible light transmittance of the PDLC film was, the higher the effect of preventing window glare was. Similarly, the PDLC film with a low transmittance also showed a high daylight performance with a low annual discomfort daylight illuminance ratio. To examine the building energy analysis result in Section 5.1, the lower SHGC was, the higher the annual heating and cooling energy reduction effect was. By contrast, the analysis result of DGI and indoor appropriate illuminance showed that the visible light transmittance had a greater effect on the indoor daylight performance. When both energy and daylight performance were considered, type A film showed the best performance.

\subsection{Annual Building Energy Performance Evaluation Result by PDLC Window Remodeling}

In this section, the building energy consumption of the second remodeling method, i.e., applying PDLC windows inside curtain walls in old office buildings is analyzed. For the properties of the PDLC in this analysis, the optical and thermal properties derived in Section 3.3 were applied. For the glazing and frame properties of old curtain walls applied in the vision area, the optical and thermal properties of the double glazing and frame derived using LBNL's Window 7.4 and Therm 7.4 were applied. Table 15 lists the glazing and frame properties of the vision area that were used as input in EnergyPlus 8.5.

Table 15. Thermal properties of curtain wall by the application of attached PDLC window analysis model.

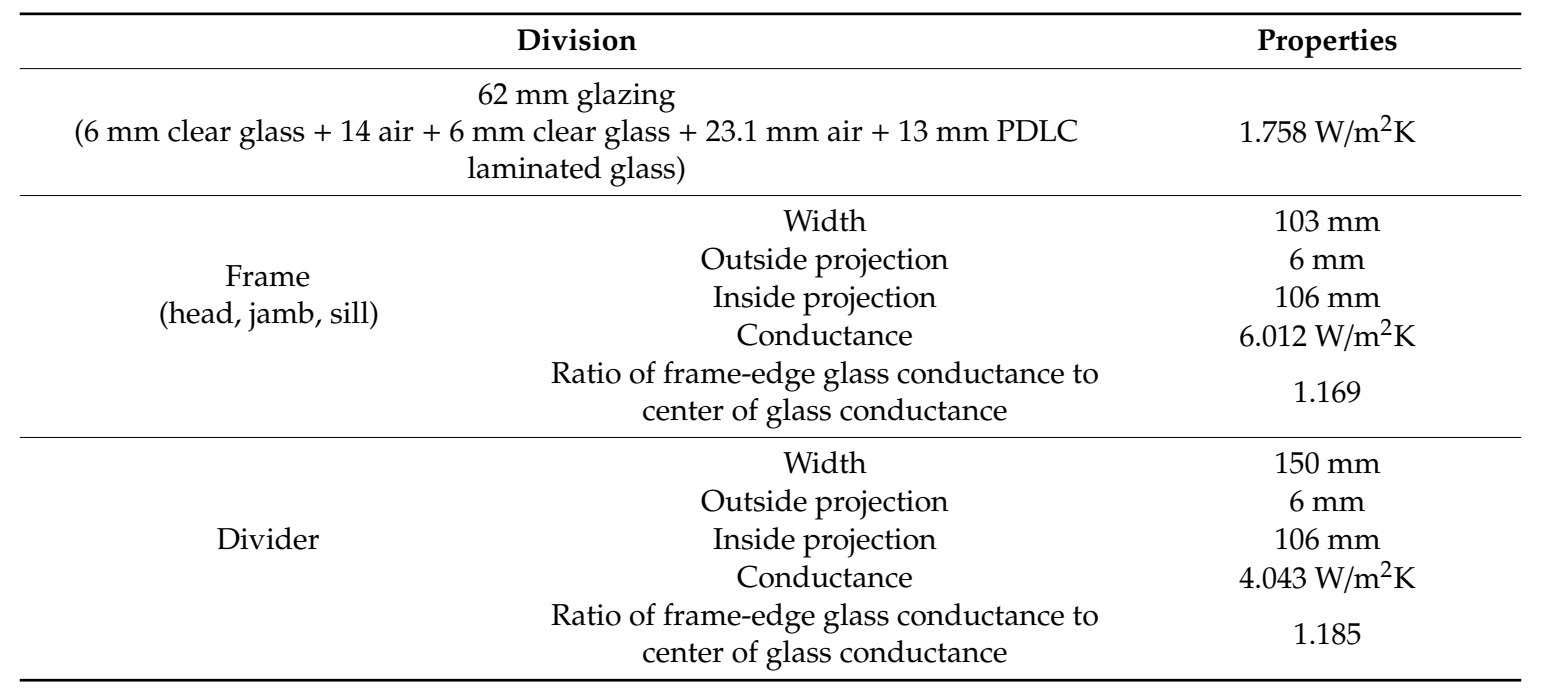

Similar to the above PDLC film analysis, the baseline was set by the energy consumption of the office building with existing old curtain walls, and the building energy performance was analyzed by applying PDLC. Table 16 outlines the building energy reduction performance according to the PDLC application. The energy consumption could be reduced by $22.4 \%, 21.3 \%, 20.5 \%$, and $18.8 \%$ for types A, B, C, and D, respectively. As with the PDLC film analysis result, the smaller the SHGC value of the PDLC was, the higher the energy reduction performance was. However, the energy reduction performance of PDLC window remodeling was higher than that of PDLC film. This is because additionally applying windows to the existing old curtain walls can improve the insulation performance and further lower SHGC. 
Table 16. Annual building energy analysis result by attached PDLC window remodeling.

\begin{tabular}{ccccc}
\hline Division & $\begin{array}{c}\text { Heating Energy } \\
\mathbf{( k W h )}\end{array}$ & $\begin{array}{c}\text { Cooling Energy } \\
\mathbf{( k W h )}\end{array}$ & $\begin{array}{c}\text { Total Energy } \\
\mathbf{( k W h )}\end{array}$ & Reducing Rate \\
\hline A type & $12,085.6$ & $33,820.6$ & $45,906.2$ & $-22.4 \%$ \\
\hline B type & $11,792.6$ & $34,753.8$ & $46,546.4$ & $-21.3 \%$ \\
\hline C type & $11,597.8$ & $35,423.6$ & $47,021.4$ & $-20.5 \%$ \\
\hline D type & $11,221.5$ & $36,774.8$ & $47,996.4$ & $-18.8 \%$ \\
\hline Baseline & $14,525.7$ & $44,600.8$ & $59,126.5$ & - \\
\hline
\end{tabular}

In Section 5.1, the heating energy consumption increased when the PDLC film for remodeling was applied, but the heating energy could be reduced by PDLC window remodeling as shown in Figure 12. This is because applying the PDLC window can improve the insulation performance and further decrease the annual total heating and cooling energy compared with the use of PDLC film.

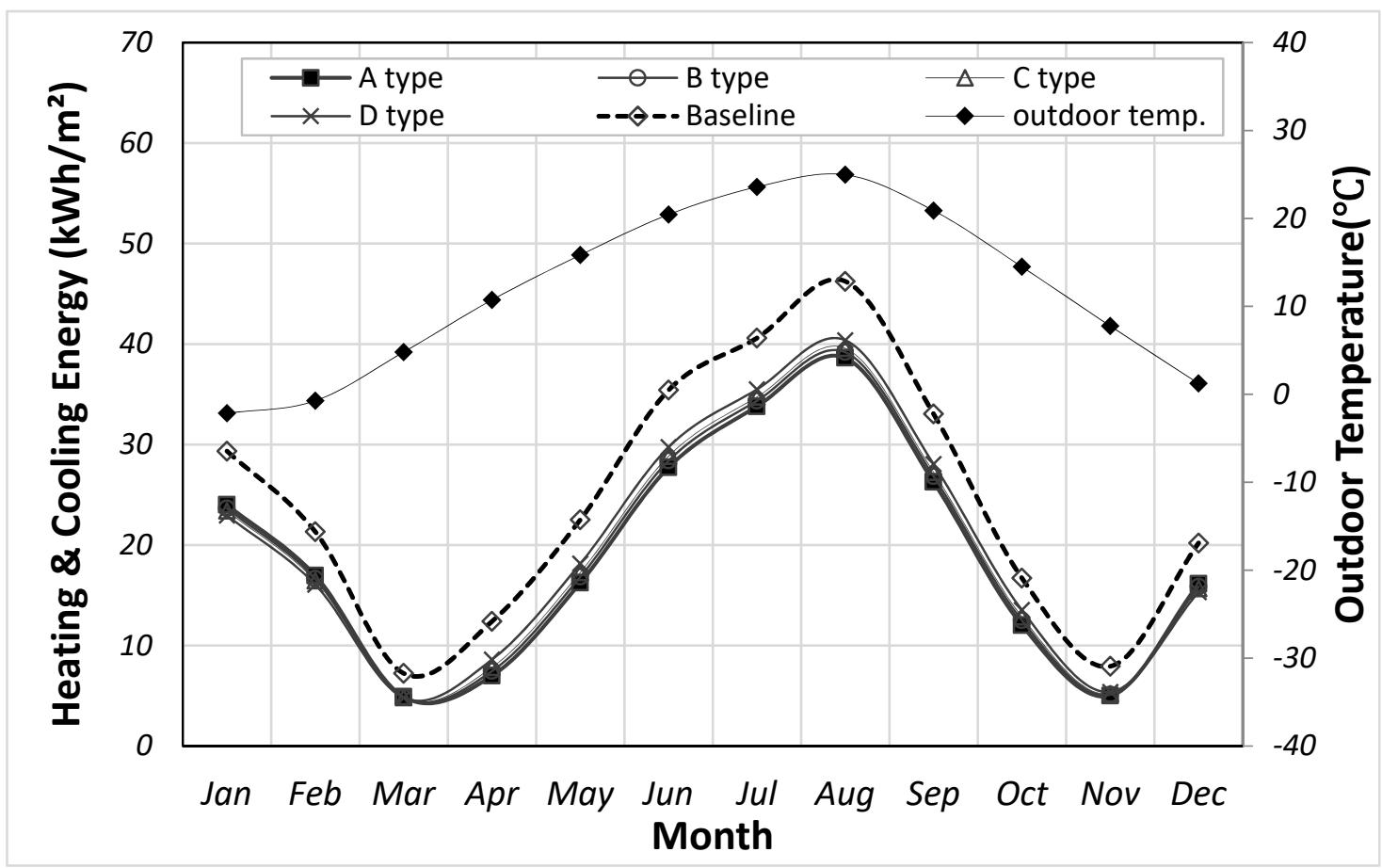

Figure 12. Analysis result of monthly heating and cooling energy consumption by PDLC film type.

However, the PDLC window had a lower effect on the cooling energy reduction amount than the PDLC film. The reason for this seems to be that an air layer of $23.1 \mathrm{~mm}$ formed when a PDLC window was additionally applied when remodeling existing old curtain walls and the temperature of the air layer-increased by solar radiation-affected the increase of cooling energy. In the case of the double glazing in the existing old curtain walls, the solar radiation that penetrated into the $23.1 \mathrm{~mm}$ air layer added by remodeling increased due to the high SHGC. The solar radiation through the PDLC window with a low solar transmittance can be blocked, but the temperature of the $23.1 \mathrm{~mm}$ air layer rose due to the greenhouse effect, and the surface temperature of the PDLC window also increased. Thus, indoor heat gain seems to have increased by radiant heat.

As a comparison, the heating energy of the PDLC film increased more than that of the existing old curtain walls, but the heating energy of the PDLC window could be reduced. Furthermore, the cooling energy could be reduced by both methods, but the PDLC film had a higher reduction performance. In terms of the annual total heating and cooling energy, the PDLC window remodeling was more 
effective because it can reduce both heating and cooling energy. The PDLC window remodeling is expected to provide comfortable indoor space throughout the year in terms of indoor thermal comfort because it can reduce the annual heating and cooling energy.

\subsection{Daylight Performance Evaluation Result by PDLC Window Remodeling}

In this section, daylight performance is examined through an analysis of discomfort glare reduction performance and annual indoor appropriate illuminance ratio when the second remodeling method of the PDLC window was applied.

First, the discomfort glare was analyzed. The annual daylight luminance graphs in Figure 13 show that the lower the visible light transmittance of the PDLC window was, the lower the annual average luminance was and it becomes visible light transmittance. To examine the data in the graphs, the annual average luminance was $41,194.9 \mathrm{~cd} / \mathrm{m}^{2}, 60,495.2 \mathrm{~cd} / \mathrm{m}^{2}, 46,909.6 \mathrm{~cd} / \mathrm{m}^{2}, 85,604.8 \mathrm{~cd} / \mathrm{m}^{2}$, for types A, B, C, and D, respectively, which is lower by $72.3 \%, 59.3 \%, 68.5 \%$, and $42.5 \%$, relative to the baseline, respectively.
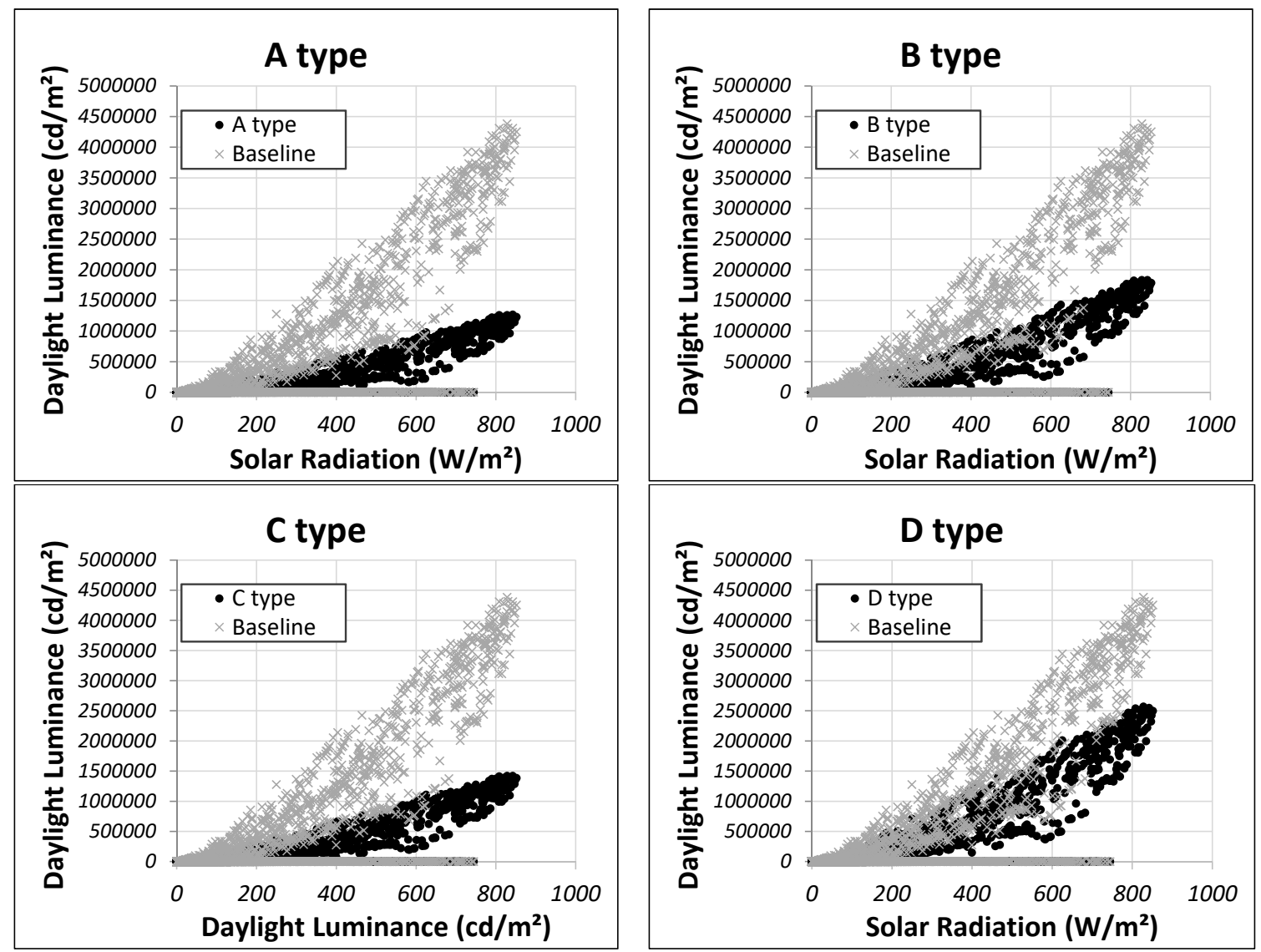

Figure 13. Annual daylight luminance analysis result by analysis result by PDLC film type.

The PDLC window remodeling was more effective in suppressing glare because it can further lower the luminance than the PDLC film remodeling by approximately $15-20 \%$. This is because, as analyzed in Section 5.2, the visible light transmittance has a dominant effect on luminance; hence, the PDLC window remodeling method with a low visible light transmittance is more effective in preventing glare

For the second evaluation of daylight performance, DGI was analyzed. For this analysis, the annual time ratio corresponding to a DGI of 22 or higher was analyzed, and the DGI analysis results are shown in the left graph in Figure 14. The PDLC window remodeling decreased the visible light transmittance 
more than the PDLC film remodeling. Therefore, the PDLC window remodeling method was more effective in reducing the discomfort glare corresponding at a DGI of 22 or higher.
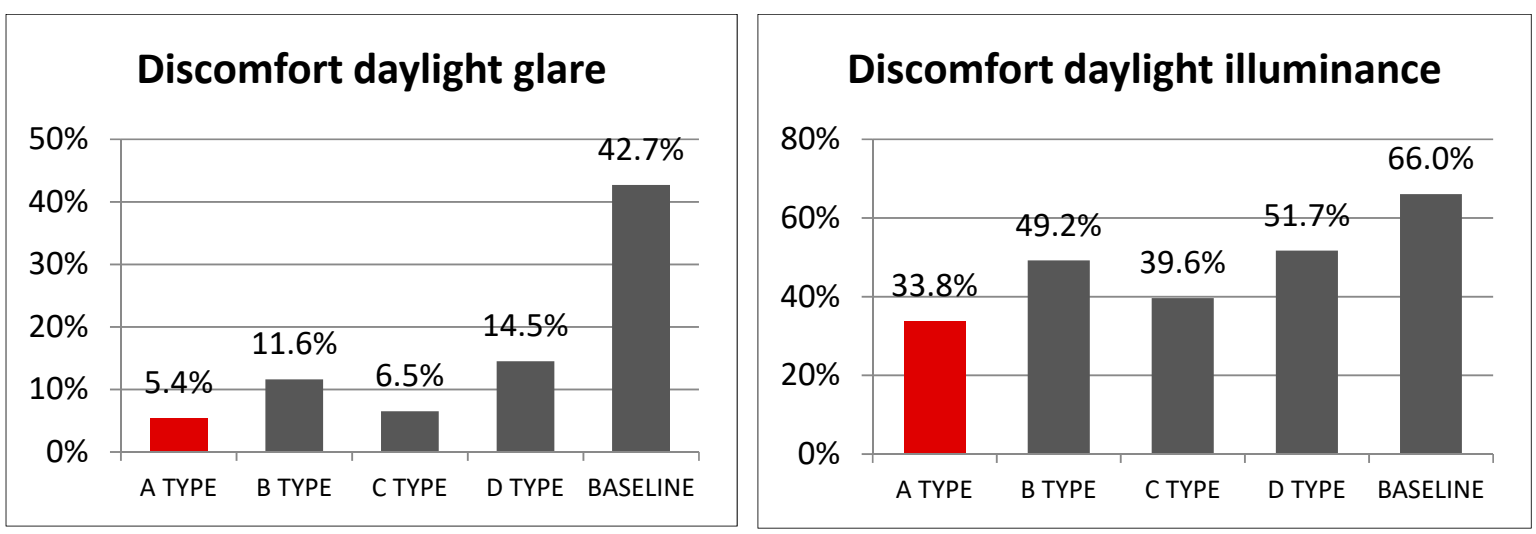

Figure 14. Annual time ratio of 22 or higher DGI (left) and annual time ratio of discomfort daylight illuminance (right).

The annual time ratio of DGI 22 or higher was $7.8 \%$ for A type when the PDLC film was applied and it decreased to $5.4 \%$ when the PDLC window was applied. It decreased from $18.2 \%$ to $11.6 \%$ for B type, from $8.8 \%$ to $6.5 \%$ for C type, and from $34.2 \%$ to $14.5 \%$ for D type.

In Section 5.2, a visible light transmittance lower than $40 \%$ was effective in the PDLC film remodeling for glare prevention, In the case of the PDLC window, the annual average luminance can be reduced by $28.2-37.3 \%$ relative to that of the existing old curtain walls according to the four types of PDLC. Moreover, PDLC can be sufficiently used as a shading device because the visible light transmittance is lower than $40 \%$ in all the PDLC types.

Next, the indoor daylight illuminance performance by PDLC film remodeling was analyzed. The graph on the right in Figure 14 shows the annual time ratio of the annual daylight illuminance that does not correspond to 150-1500 lx.

An analysis of the discomfort daylight illuminance revealed the same pattern as for the PDLC film remodeling method. In general, the PDLC window method showed a higher appropriate illuminance ratio than the PDLC film method. Type A showed the lowest discomfort daylight illuminance ratio of $33.8 \%$. Hence, the PDLC window remodeling was found to be a more effective method for securing indoor illuminance than the PDLC film method. Among the PDLC film types, type A showed the best daylight performance, followed by types $C, B$, and D.

\subsection{Evaluation Result of Integrated Heating and Cooling Energy and Daylight Performance}

The building energy performance and daylight performance were analyzed for two remodeling methods (PDLC film and PDLC window) for four PDLC types from Sections 5.1-5.4. Even though the advantages and disadvantages of each PDLC remodeling method could be verified, an integrated evaluation is required. In this section, the energy and daylight environment analysis result data were unified by one index and integrated performance evaluation was performed. The performance evaluation index is the Integrated Energy and Daylight Performance Index (EDPI), which evaluates the actual value of each component of energy, DGI, and indoor illuminance by converting them into percentiles through comparison of maximum and minimum values [49].

According to the equation for the EDPI, a higher value produces a higher performance score. The DGI from data in Table 11 was re-calculated to a ratio corresponding to a DGI of 22 or lower, and the indoor appropriate illuminance was changed to a ratio corresponding to the 150-1500 lx range. For energy, the sum of heating and cooling energy was applied. Since a lower energy score indicates 
higher performance and is inversely proportional to the EDPI score, the EDPI was determined by subtracting the value of Equation (2) from 100.

$$
E D P I_{i j}=\frac{\text { Actual } X_{i j} \text { value }- \text { Minimum } X_{i j} \text { value }}{\text { Maximum } X_{i j} \text { value }- \text { Minmum } X_{i j} \text { value }} \times 100
$$

Table 17 and Figure 15 show the EDPI analysis results. The best condition from the analysis result was the window remodeling method applying type A PDLC. The window modeling method using type A PDLC showed the smallest heating and cooling energy consumption, the annual ratio of DGIs lower than 22 was the highest, and the annual indoor appropriate illuminance ratio was also the highest. Thus, it obtained the EDPI score of 100. This could be expected to some degree when compared with the PDLC film remodeling method in Section 5.4.

Table 17. Integrated energy and daylight performance evaluation data analysis through the Integrated Energy and Daylight Performance Index (EDPI).

\begin{tabular}{|c|c|c|c|c|c|c|}
\hline & \multirow{2}{*}{ Division } & \multicolumn{3}{|c|}{ Element (i) } & \multirow{2}{*}{ Total } & \multirow{2}{*}{ Avg. } \\
\hline & & $\begin{array}{l}\text { Energy } \\
(\mathrm{kWh})\end{array}$ & $\begin{array}{c}\text { DGI } \\
\text { Under } 22\end{array}$ & $\begin{array}{c}\text { LUX } \\
1501 x-1500 \mathrm{~lx}\end{array}$ & & \\
\hline \multirow{9}{*}{ Data (j) } & PDLC Film (A type) & $48,969.8$ & $92.2 \%$ & $62.0 \%$ & & \\
\hline & PDLC Film (B type) & $49,735.2$ & $81.8 \%$ & $45.8 \%$ & & \\
\hline & PDLC Film (C type) & $54,791.0$ & $91.2 \%$ & $51.1 \%$ & & \\
\hline & PDLC Film (D type) & $56,446.9$ & $65.8 \%$ & $39.6 \%$ & & \\
\hline & PDLC Window (A type) & $45,906.2$ & $94.6 \%$ & $66.2 \%$ & & \\
\hline & PDLC Window (B type) & $46,546.4$ & $88.4 \%$ & $50.8 \%$ & & \\
\hline & PDLC Window (C type) & $47,021.4$ & $93.5 \%$ & $60.4 \%$ & & \\
\hline & PDLC Window (D type) & $47,996.4$ & $85.5 \%$ & $48.3 \%$ & & \\
\hline & Baseline & $59,126.5$ & $57.3 \%$ & $34.0 \%$ & & \\
\hline \multirow{9}{*}{ EDPI } & PDLC Film (A type) & 76.8 & 93.4 & 87.0 & 257.3 & 85.8 \\
\hline & PDLC Film (B type) & 71.0 & 65.6 & 36.7 & 173.3 & 57.8 \\
\hline & PDLC Film (C type) & 32.8 & 90.8 & 53.2 & 176.8 & 58.9 \\
\hline & PDLC Film (D type) & 20.3 & 22.8 & 17.6 & 60.7 & 20.2 \\
\hline & PDLC Window (A type) & 100.0 & 100.0 & 100.0 & 300.0 & 100.0 \\
\hline & PDLC Window (B type) & 95.2 & 83.4 & 52.2 & 230.8 & 76.9 \\
\hline & PDLC Window (C type) & 91.6 & 97.0 & 82.0 & 270.6 & 90.2 \\
\hline & PDLC Window (D type) & 84.2 & 75.6 & 44.5 & 204.2 & 68.1 \\
\hline & Baseline & 0.0 & 0.0 & 0.0 & 0.0 & 0.0 \\
\hline
\end{tabular}

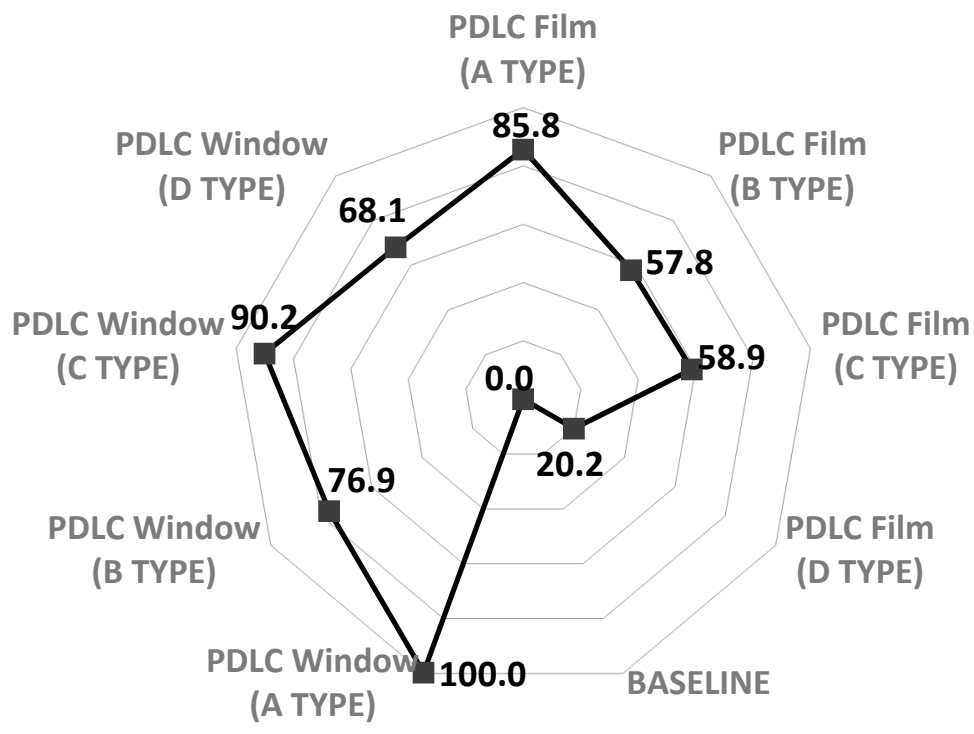

Figure 15. Integrated energy and daylight performance evaluation result through the EDPI. 
The method with the second best performance was the window remodeling method using type $C$ PDLC. This method showed the third highest performance in annual heating and cooling energy and annual indoor appropriate illuminance ratio, but the discomfort glare reduction performance was second best owing to the low visible light transmittance.

The method with the third best performance was the type A PDLC film remodeling method. Even though the type A PDLC film remodeling method was fifth in heating and cooling energy, which is normal, it showed excellent performance in discomfort glare reduction performance and the annual indoor appropriate illuminance ratio.

A general analysis of the above results shows that the window remodeling of the curtain walls in old office buildings using type A PDLC can obtain the most improved effects in terms of energy and daylight performance. However, even though the improvement of energy and daylight performance can be maximized, if the remodeling cost is also considered, the application of type A PDLC film appears to be able to obtain improvement effects while achieving economic efficiency.

\section{Conclusions}

This study proposed a remodeling method for improving the building energy and daylight performance based on the analysis of optical properties data for four types of PDLC films. In addition, the building energy consumption, discomfort glare, and indoor appropriate illuminance when remodeling is performed using PDLC films were researched. The results of this study are summarized as follows.

(1) The optical properties of four types of PDLC films were analyzed using a spectrometer. The results showed that type A and B PDLC films are effective in blocking the NIR region and have a small variation range of transmittance depending on ON/OFF switching and type C and D PDLC films have large variation ranges in the visible light and NIR regions depending on ON/OFF switching.

(2) To examine the degree of performance improvement by remodeling to improve the energy efficiency of old buildings using PDLC films, two remodeling methods were proposed. The first method was to attach a PDLC film to the double glazing of existing old curtain walls. The second method was to laminate a PDLC film between two glass substrates and configure a separate frame and attach a new window to the indoor side. The variations in thermal and optical properties when the two remodeling methods were applied to the existing curtain wall were analyzed. Then, the heating and cooling energy, discomfort glare, and indoor illuminance were analyzed using the EnergyPlus simulation tool. For the PDLC control conditions for simulation, solar radiation was blocked by switching PDLC off when discomfort glare occurs based on the DGI (daylight glare index) developed by Hopkinson.

(3) The result of building energy performance evaluation according to the glass-attached PDLC film remodeling showed that types $\mathrm{A}, \mathrm{B}, \mathrm{C}$, and D reduced energy by $17.0 \%, 15.8 \%, 7.3 \%$, and $3.1 \%$, respectively, compared with the office building with old curtain walls. When the annual discomfort glare time ratio was analyzed, the office building with old curtain walls generated an annual discomfort glare ratio of $42.7 \%$. However, the attachment of PDLC film decreased the discomfort glare generation time ratio to $7.8 \%, 18.2 \%, 8.8 \%$, and $34.2 \%$ for types $\mathrm{A}$, $\mathrm{B}, \mathrm{C}$, and D, respectively. When the annual indoor daylight discomfort illuminance ratio was analyzed, it was $66.0 \%$ for the office building with existing old curtain walls. However, when the PDLC film was attached, it improved to $38.0 \%, 54.2 \%, 48.9 \%$, and $60.4 \%$ for types A, B, C, and $\mathrm{D}$, respectively. Therefore, the PDLC film-attached remodeling was shown to be effective in improving the building energy efficiency, reducing the discomfort glare, and securing useful indoor illuminance.

(4) When the building energy performance of the remodeling method of forming and attaching a window with PDLC was evaluated, the energy consumption could be reduced by $22.4 \%, 21.3 \%$, $20.5 \%$, and $18.8 \%$ for types $\mathrm{A}, \mathrm{B}, \mathrm{C}$, and D, respectively, compared with the office building 
with old curtain walls. The annual discomfort glare time ratio was analyzed, office buildings generated discomfort glare during $42.7 \%$ of the year. However, after PDLC window remodeling, the discomfort glare generation time ratio decreased to $5.4 \%, 11.6 \%, 6.5 \%$, and $14 . \%$ for types A, B, C, and D, respectively. Furthermore, the annual indoor daylight discomfort illuminance ratio of office buildings with existing old curtain walls was $66.0 \%$, but when the PDLC film was attached, it improved to $33.8 \%, 49.2 \%, 39.6 \%$, and $51.7 \%$ for types $\mathrm{A}, \mathrm{B}, \mathrm{C}$, and $\mathrm{D}$, respectively. Therefore, the PDLC window remodeling had a greater performance improvement effect than the PDLC film attached remodeling method in terms of building energy and daylight environment.

(5) The EDPI analysis result showed that the best conditions were achieved with the window remodeling method using type A PDLC. The window remodeling method using type A PDLC had the smallest annual heating and cooling energy consumption and the highest annual ratio of DGIs lower than 22, and the annual indoor appropriate illuminance ratio was also the highest, acquiring an EDPI score of 100 points. The second best performance method was the window remodeling method using type C PDLC. Its annual heating and cooling energy and annual indoor appropriate illuminance ratio were average, but it showed excellent discomfort glare reduction performance owing to a low visible light transmittance. The third best performance method was the type A PDLC film remodeling method. The type A PDLC film remodeling method showed average levels of heating and cooling energy but showed good results in terms of discomfort glare reduction performance and annual indoor appropriate illuminance ratio.

(6) To generally summarize the results, window remodeling of old office buildings curtain walls using type A PDLC is expected to bring the most significant improvement effects in terms of energy and daylight performance. Even though the window remodeling method can maximize the improvement effect, when remodeling costs are also considered, applying the type A PDLC film could obtain economic efficiency as well as improvement effect.

In this study, the building energy reduction and daylight performance improvement effects of remodeling old buildings using PDLC films were analyzed. The analysis results showed that both remodeling methods using PDLC films were effective in terms of heating and cooling energy reduction and daylight performance improvement. Among the four types of PDLC films, type A film with a low SHGC was found to be the most effective. However, this study has a few limitations. First, the analysis variables such as the shape of the analysis model, window area ratio, use schedule, internal gain, and weather data for old office buildings are limited, and the HVAC system was not reflected. Therefore, it is impossible to obtain the same performance improvement effect as in this study for all buildings. Second, when setting the PDLC control conditions, this study considered glare prevention, which is the most basic function of shading devices as the most important variable. In addition, it was assumed that solar radiation was blocked when discomfort glare occurs based on the DGI. However, the possibility of realistically implementing a sensor that can measure the DGI is uncertain.

Therefore, in the follow-up study, data for standardization considering the use, shape, window area ratio, and use schedule of various buildings will be built. Furthermore, the relationships of DGI with external solar radiation, external illuminance, and daylight luminance will be identified, and PDLC control methods based on external environmental variables that are actually available will be researched.

Author Contributions: Conceptualization, M.O. and C.L.; methodology, M.O. and J.P.; software, M.O.; validation, K.L.; formal analysis, M.O. and C.L.; investigation, J.P.; resources, J.P.; data curation, J.P.; writing—original draft preparation, M.O.; writing-review and editing, S.T.; visualization, K.L.; supervision, S.T.; project administration, J.P. and S.T.; funding acquisition, M.O.

Funding: This research was funded by the Ministry of Land, Infrastructure, and Transport of the Korean Government. Grant number: 18CTAP-C142184-01. This research was supported by a grant from the Technology Advancement Research Program (TARP), funded by the Ministry of Land, Infrastructure, and Transport of the Korean government. Grant number: 18CTAP-C142184-01

Conflicts of Interest: The authors have no conflict of interest to declare. 


\section{References}

1. Kassai, M. Experimental investigation of carbon dioxide cross-contamination in sorption energy recovery wheel in ventilation system. Build. Serv. Eng. Res. Technol. 2018, 39, 463-474. [CrossRef]

2. Kassai, M.; Simonson, C.J. Performance investigation of liquid-to-air membrane energy exchanger under low solution/air heat capacity rates ratio conditions. Build. Serv. Eng. Res. Technol. 2015, 36, 535-545. [CrossRef]

3. Lee, K.H.; Koo, B.K.; Park, B.R.; Ahn, Y.H. The development of an energy-efficient remodeling freamework in South Korea. Habitat. Int. 2015, 53, 430-441. [CrossRef]

4. Paoletti, G.; Pascual, P.R.; Pernetti, R.; Lollini, R. Nearly Zero Energy Buildings: An Overview of the Main Construction Features across Europe. Buildings 2017, 7, 43. [CrossRef]

5. Domjan, S.; Arkar, C.; Begelj, Ž.; Medved, S. Evolution of all-glass nearly Zero Energy Buildings with respect to the local climate and free-cooling techniques. Build. Environ. 2019, 160, 106183. [CrossRef]

6. Oh, M.H.; Lee, K.H.; Yoon, J.H. Automated control strategies of inside slat-type blind considering visual comfort and building energy performance. Energy Build. 2012, 55, 728-737. [CrossRef]

7. Moschella, A.; Gagliano, A.; Lo Faro, A.; Mondello, A.; Salemi, A.; Sanfilippo, G. A Methodology for an Integrated Approach for Seismic and Energy Refurbishment of Historic Buildings in Mediterranean Area. Sustainability 2018, 10, 2448. [CrossRef]

8. Tina, G.M.; Gagliano, A.; Nocera, F.; Patania, F. Photovoltaic glazing: Analysis of thermal behavior and indoor comfort. Energy Procedia 2013, 42, 367-376. [CrossRef]

9. Rezaei, S.D.; Shannigrahi, S.; Ramakrishna, S. A review of conventional, advanced, and smart glazing technologies and materials for improving indoor environment. Sol. Energy Mater. Sol. Cells 2017, 159, 26-51. [CrossRef]

10. Casini, M. Active dynamic windows for buildings: A review. Renew. Energy 2018, 119, 923-934. [CrossRef]

11. Reilly, S.; Arasteh, D.; Selkowitz, S.E. Thermal and optical analysis of switchable window glazings. Sol. Energy Mater. 1991, 22, 1-14. [CrossRef]

12. Jelle, B.P.; Hymd, A.; Gustavsen, A.; Arasteh, D.; Goudy, H.; Hart, R. Fenestration of today and tomorrow; a state-of-the-art review and future research opportunities. Sol. Energy Mater. Sol. Cells 2012, 96, 1-28. [CrossRef]

13. Baetens, R.; Jelle, B.P.; Gustavsen, A. Properties, requirements, and possibilities of smart windows for dynamic daylight and solar energy control in buildings: A state-of-art review. Sol. Energy Mater. Sol. Cells 2010, 94, 87-105. [CrossRef]

14. Ghosh, A.; Norton, B. Durability of switching behavior after outdoor exposure for a suspended particle device switchable glazing. Sol. Energy Mater. Sol. Cells 2017, 163, 178-184. [CrossRef]

15. Ghosh, A.; Norton, B.; Duffy, A. Daylighting performance and glare calculation of a suspended particle device switchable glazing. Sol. Energy 2016, 132, 114-128. [CrossRef]

16. Ghosh, A.; Mallick, T.K. Evaluation of colour properties due to switching behaviour of a PDLC glazing for adaptive building integration. Renew. Energy 2018, 120, 126-133. [CrossRef]

17. Lampert, C.M. Large-area smart glass and integrated photovoltaics. Sol. Energy Mater. Sol. Cells 2003, 76, 489-499. [CrossRef]

18. Lampert, C.M. Smart switchable glazing for solar energy and daylight control. Sol. Energy Mater. Sol. Cells 1998, 52, 207-221. [CrossRef]

19. Ajaji, Y.; André, P. Thermal comfort and visual comfort in an office building equipped with smart electrochromic glazing: An experimental study. Energy Procedia 2015, 78, 2464-2469. [CrossRef]

20. Tavares, P.F.; Gaspar, A.R.; Martins, A.G.; Frontini, F. Evaluation of electrochromic windows impact in the energy performance of buildings in Mediterranean climates. Energy Policy 2014, 67, 68-81. [CrossRef]

21. Fernandes, L.L.; Lee, E.S.; Ward, G. Lighting energy savings potential of split-pane electrochromic windows controlled for daylighting with visual comfort. Energy Build. 2013, 61, 8-20. [CrossRef]

22. Piccolo, A.; Pennisi, F. Simone, Daylighting performance of an electrochomic window in a small-scale test-cell. Sol. Energy 2009, 83, 832-844. [CrossRef]

23. Lee, E.S.; Yazdanian, M.; Selkowitz, S. The Energy-Savings Potential of Electrochromic Windows in the US Commercial Buildings Sector; Lawrence Berkeley National Laboratory Report LBL-54966; Lawrence Berkeley National Laboratory: Alameda, CA, USA, 2014.

24. Papaefthimiou, S.; Syrrakou, E.; Yianoulis, P. Energy performance assessment of an electrochromic window. Thin Solid Films 2006, 502, 257-264. [CrossRef] 
25. DeForest, N.; Shehabi, A.; Garcia, G.; Greenbalt, J.; Masanet, E.; Lee, E.S.; Selkowitz, S.; Milliron, D.J. Regional performance targets for transparent near-infrared switching electrochromic window glazings. Build. Environ. 2013, 61, 160-168. [CrossRef]

26. Cannavale, G.E.; Eperon, P.; Cossari, A.; Abate, H.J.; Snaith, G.; Gigli, P. Photovoltachromic cells for building integration. Energy Environ. Sci. 2015, 8, 1578-1584. [CrossRef]

27. Granqvist, C.G.; Bayrak Pehlivan, I.; Niklasson, G.A. Electrochromics on a roll: Web-coating and lamination for smart windows. Surf. Coat. Technol. 2017, 6-11. [CrossRef]

28. Rottmann, M.; Kraft, A.; Heckner, K.H.; Hausler, T.; Fischer, U.; Stenzel, H. Large-area electrochromic safety glass; switching behaviour and transmission control of solar radiation. In Proceedings of the 9th International Glass Conference on Glass Processing Days, Tampere, Finland, 17-20 June 2005.

29. Muehling, O.; Seeboth, A.; Haeusler, T.; Ruhmann, R.; Potechius, E.; Vetter, R. Variable solar control using thermotropic core/shell particles. Sol. Energy Mater. Sol. Cells 2019, 93, 1510-1517. [CrossRef]

30. Feng, W.; Zou, L.; Gao, G.; Wu, G. Gasochromic smart window: Optical and thermal properties, energy simulation and feasibility analysis. Sol. Energy Mater. Sol. Cells 2016, 144, 316-323. [CrossRef]

31. Nitz, P.; Hartwig, H. Solar control with thermotropic layers. Sol. Energy 2005, 79, 573-582. [CrossRef]

32. Granqvist, C.G. Recent progress in thermochromics and electrochromics: A brief survey. Thin Solid Films 2016, 614, 90-96. [CrossRef]

33. LBNL. Available online: https://windows.lbl.gov/software/optics (accessed on 14 September 2019).

34. LBNL. Available online: https://windows.lbl.gov/software/window (accessed on 14 September 2019).

35. LBNL. Available online: https://windows.lbl.gov/software/therm (accessed on 14 September 2019).

36. KSCI. Available online: https://standard.go.kr/ (accessed on 9 June 2018).

37. Finlayson, E.U.; Arasteh, D.K.; Huizenga, C.; Rubin, M.D.; Reilly, M.S. WINDOW 4.0: Documentation of Calculation Procedures; Lawrence Berkeley National Laboratory Report LBL-33943; Lawrence Berkeley National Laboratory: Alameda, CA, USA, 1993.

38. EnergyPlus. EnergyPlus Input Output Reference. The Encyclopedic Reference to EnergyPlus Input and Output. Available online: http://www.energyplus.gov (accessed on 26 September 2019).

39. EnergyPlus, EnergyPlus Engineering Reference. The Reference to EnergyPlus Calculations. Available online: http://www.energyplus.gov (accessed on 26 September 2012).

40. Arasteh, D.K.; Reilly, M.S.; Rubin, M.D. A versatile procedure for calculating heat transfer through windows, American Society of Heating, Refrigeration and Air-Conditioning Engineers. ASHRAE Trans. 1989, 95, 755-765.

41. Arasteh, D.K.; Kohler, J.C.; Griffith, B.T. Draft, Modeling Windows in EnergyPlus with only U, SHGC, and Optionally VT; Lawrence Berkeley National Laboratory: Alameda, CA, USA, 2009.

42. Winkelmann, F.; Selkowitz, S. Day-Lighting Simulation in DOE-2: Theory, Validation and Applications; Lawrence Berkeley National Laboratory: Alameda, CA, USA, 1985.

43. Lomanowski, B.A.; Wright, J.L. Modeling fenestration with shading devices in building energy simulation: A practical approach. In Proceedings of the 11th International IBPSA Conference, Glasgow, Scotland, 27-30 July 2009.

44. Petherbridge, P.; Hopkinson, R.G. Hopkinson. Discomfort Glare and the Lighting of Buildings. Trans. Illum. Eng. Soc. 1950, 15, 39-79.

45. Winkelmann, F. Modeling Windows in EnergyPlus. In Proceedings of the 7th International IBPSA Conference, Rio di Janeiro, Brazil, 13-15 August 2001.

46. The Korean Ministry of Land. Transport and Maritime Affairs, Standard for Energy Saving Design in Buildings; The Korean Ministry of Land: Sejong, Korea, 2019.

47. Refrigerating and Air-Conditioning Engineers, Inc. ASHRAE Fundamentals Handbook, American Society of Heating; 1791 tullie circle, N.E.; Refrigerating and Air-Conditioning Engineers, Inc.: Atlanta, GA, USA, 2009.

48. Hopkinson, R.G. Glare from daylighting in buildings. Appl. Ergon. 1972, 3, 206-215. [CrossRef]

49. Oh, M.; Park, J.; Roh, S.; Lee, C. Deducing the optimal control method for electrochromic triple glazing through an integrated evaluation of building energy and daylight performance. Energies 2018, 11, 2205. [CrossRef]

(C) 2019 by the authors. Licensee MDPI, Basel, Switzerland. This article is an open access article distributed under the terms and conditions of the Creative Commons Attribution (CC BY) license (http://creativecommons.org/licenses/by/4.0/). 